\title{
SHAREHOLdER PROTECTION: \\ A LEXIMETRIC APPROACH
}

\author{
PRIYA P. LELE* \\ MATHIAS M. SIEMS*
}

25 July 2006

\begin{abstract}
In this article we build a new and meaningful shareholder protection index for five countries and code the development of the law for over three decades. This quantification of legal rules ("leximetrics") provides interesting possibilities for comparing variations across time series and across legal systems. For instance, our study finds, that in all of our panel countries shareholder protection has been improving in the last three decades; that the protection of minority against majority shareholders is considerably stronger in "blockholder countries" as compared to the non-blockholder countries and that convergence in shareholder protection is taking place since 1993 and is increasing since 2001. Finally, our examination of the legal differences between the five countries does not confirm the distinction between common law and civil law countries.
\end{abstract}

JEL Classification: G00, G30, G38, K00, K22, N20, N40, P50.

Keywords: Shareholder protection, leximetrics, numerical comparative law, law and finance, La Porta et al., LLSV, coding, comparative company law, comparative corporate law, comparative corporate governance, legal origins, legal development, convergence.

\footnotetext{
* Centre for Business Research, University of Cambridge; e-mail: p.lele@cbr.cam.ac.uk and m.siems@cbr.cam.ac.uk; All comments are welcome.
} 


\section{Table of Contents}

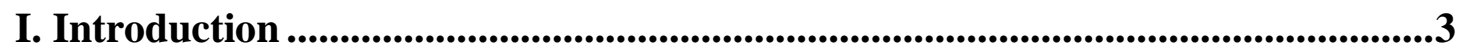

II. The problems with existing indices ..............................................................4

III. Building a meaningful shareholder protection index ...........................................8

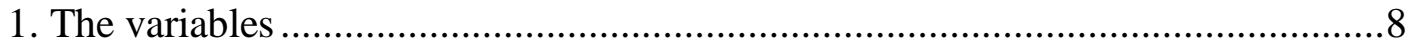

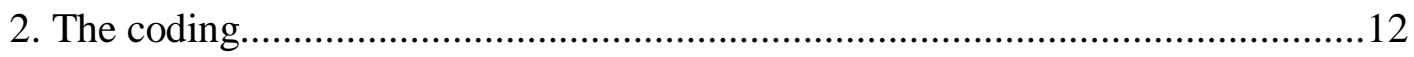

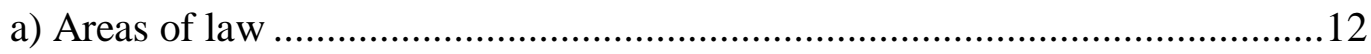

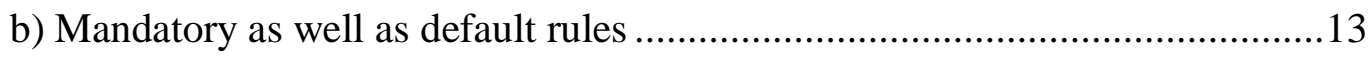

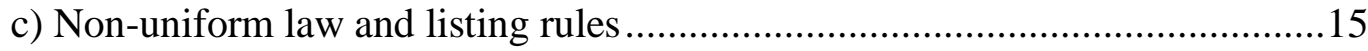

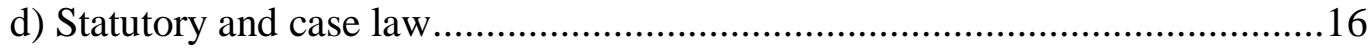

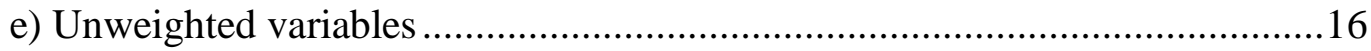

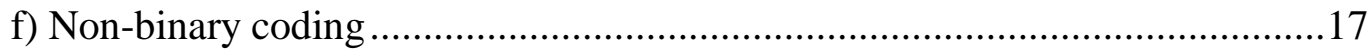

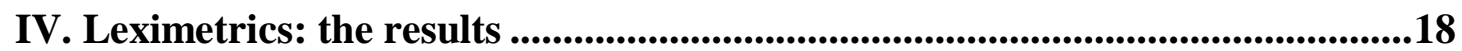

1. General shareholder protection aggregate ....................................................18

2. Aggregates of specific groups of variables ….................................................24

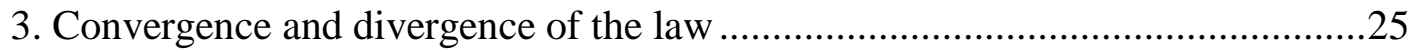

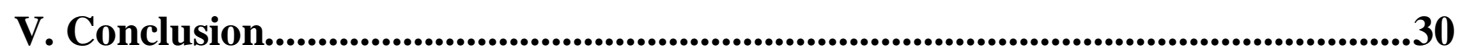

Annex I: Shareholder protection index (variables)................................................32

Annex II: Shareholder protection index (extract - France) .................................35 


\title{
SHAREHOLDER PRotection:
}

\section{A LEXIMETRIC APPROACH}

\author{
PRIYA P. LELE* \\ MATHIAS M. SIEMS*
}

25 July 2006

\section{A. INTRODUCTION}

The discussion of "shareholder protection" has various dimensions: it is topical in the context of the EU Commission's proposal to harmonise some aspects of shareholder rights in the EU. ${ }^{1}$ It is significant for the consideration of good corporate governance. ${ }^{2}$ And time and again comes to the forefront in the growing literature on "law and finance". Following the pioneering work of a group of financial economists, ${ }^{3}$ there is an increasing trend to quantify the law in relation to shareholder protection. However, in our view, this has not been done in a satisfactory manner. Thus, Section B identifies some of the problems with the existing indices. Section $\mathrm{C}$ discusses the building of a more meaningful shareholder protection index for this article, in particular it addresses, the question of selection of variables and method of coding. Section D pre-

\footnotetext{
${ }^{*}$ Centre for Business Research (CBR), University of Cambridge. We are grateful to the comments of John Armour, Brian Cheffins, Paul Davies, Simon Deakin, Sonja Fagernäs, Cynthia Williams and the participants at the CBR summit on innovation and governance, Cambridge and the World Economy \& Finance Workshop, London. The usual disclaimer applies.

${ }^{1}$ Commission Proposal for a Directive on the Exercise of Shareholders' Voting Rights of 5. January 2006, $\operatorname{COM}(2005) 685$ final; for a critical comment see MM Siems, "The Case Against Harmonisation of. Shareholder Rights" (2005) 6 European Business Organization Law Review 539.

${ }^{2}$ LA Bebchuk, "The Case for Increasing Shareholder Power" (2005) 118 Harvard Law Review 835; LA Bebchuk, "The Case for Shareholder Access: A Response to the Business Roundtable" (2005) 55 Case Western Reserve Law Review 557; see also LA Bebchuk and JM Fried, Pay Without Performance: The Unfulfilled Promise of Executive Compensation (Cambridge, Mass., Harvard University Press, 2004).

${ }^{3}$ See infra, Section B.
} 
sents some of the results that are indicative of interesting possibilities that a leximetric approach $^{4}$ opens up into the study of comparative shareholder protection law and Section E concludes.

It is hoped that our results contribute to the contemporary discussion on comparative company law and corporate governance. Adopting a leximetric approach, we have made some interesting findings on questions such as which of the studied countries scores the maximum on our shareholder protection index, how much legal systems have changed over the years, whether differences follow the distinction into civil-law and common-law countries, and whether the laws on shareholder protection are converging or diverging. ${ }^{5}$

As a point of clarification, it should be noted that this article is about "leximetrics" and not "econometrics". "Leximetrics" can be understood as every quantitative measurement of law. To be sure, the coding of shareholder rights can be the first part of an econometric study which seeks to find correlations between legal and economic data. Since this will, however, be part of a further study, ${ }^{6}$ this article only analyses the quantification of the law on shareholder protection in different countries.

\section{B. THE PROBLEMS WITH EXISTING INDICES}

The most popular shareholder protection index so far is the one constructed in $\mathrm{La}$ Porta et al's article on "Law and Finance". 7 This index uses eight variables as proxies for shareholder protection in 49 countries. These variables code the law for "one share one vote", "proxy by mail allowed", "shares not blocked before the meeting", "cumulative voting", "oppressed minorities mechanism", "pre-emptive rights to new issues",

\footnotetext{
${ }^{4}$ This term was first used in RD Cooter and T Ginsburg, "Leximetrics: Why the Same Laws are Longer in Some Countries than Others" (2003), available at http://ssrn.com/abstract=456520 (accessed on 24 July 2006).

${ }^{5}$ For details see infra, Sections D and E.

${ }^{6}$ This article promises to be the first of a series of papers that we intend to produce as a part of the project on "Law, Finance and Development" at the Centre for Business Research, University of Cambridge, UK. This project aims to consider the mechanisms by which legal institutions shape national financial systems, so as to identify the implications of legal reform for economic development. It is an interdisciplinary project which will combine qualitative and quantitative research methodology to yield a uniquely complete set of empirical results.
}

${ }^{7}$ R La Porta et al, "Law and Finance” (1998) 106 Journal of Political Economy 1113. 
"share capital required to call an extraordinary shareholder meeting", and "mandatory dividend".

Since the publication of "Law and Finance" in 1998 many studies have used these variables on shareholder protection. ${ }^{8}$ However, as admitted in their most recent paper, ${ }^{9}$ the initial index has also been subjected to many criticisms. For instance, Spamann, Cools and Braendle have criticised the ad hoc selection of variables and found various coding errors. ${ }^{10}$ Pistor has gone a step ahead and extended the number of variables in order to capture particular problems for the transition economies of Eastern Europe and the former Soviet Union. ${ }^{11}$

To elaborate, the first problem is the very limited number of variables, which hardly provides a meaningful picture of the legal protection of shareholders. ${ }^{12}$ To be sure, one cannot take all aspects of shareholder protection into account. The company law of most countries consists of several hundred sections or articles, so that the coding of all the details would lead to an unworkable index of several hundred (or more like thousand) variables. Thus, it is indeed necessary to construct a limited number of variables. But the selection of variables must be intelligible and wide enough to function as a proxy for shareholder protection in general, which is not the case with La Porta et al's eight variables. They do not fully capture the most significant aspects of the law. ${ }^{13}$ For instance, although the variables for "one share one vote", "proxy by

\footnotetext{
${ }^{8}$ A Dyck and L Zingales, "Private Benefits of Control: An International Comparison" (2004) 59 Journal of Finance 537; AN Licht et al, "Culture, Law, and Corporate Governance" (2005) 25 International Review of Law and Economics 229; M Pagano and P Volpin, "The Political Economy of Corporate Governance" (2005) 95 American Economic Review 1005; further references in Holger Spamann, "On the Insignificance and/or Endogeneity of La Porta et al's 'Anti-Director Rights Index' under Consistent Coding” (2006), 1; available at http://ssrn.com/abstract=894301 (accessed on 24 July 2006).

9 S Djankov et al, "The Law and Economics of Self-Dealing" (2005), 27, available at http://ssrn.com/abstract=864645 (accessed on 24 July 2006).

${ }^{10}$ Spamann, supra n 8; S Cools, "The Real Difference in Corporate Law between the United States and Continental Europe: Distribution of Powers" (2005) 30 Delaware Journal of Corporate Law 697; UC Braendle, "Shareholder Protection in the USA and Germany - 'Law and Finance' Revisited" (2006) 7 German Law Journal 257.

${ }^{11}$ K Pistor, "Patterns of Legal Change: Shareholder Protection and Creditor Rights in Transition Economies" (2000) 1 European Business Organization Law Review 59; see also Pistor et al, "Law and Finance in Transition Economies" (2000) 8 Economics of Transition 325.

${ }^{12}$ For a similar point, see Braendle, supra n 10, 264.

${ }^{13}$ See also JC Coffee, "The Rise of Dispersed Ownership: The Role of Law in the Separation of Ownership and Control" (2001) 111 Yale Law Journal 1, 4 n 6 where he states, "by no means is it here implied that these rights are unimportant, but only that they supply partial and sometimes easily outflanked safeguards, which have little to do with the protection of control and the entitlement to a control premium." Similar observations have been made with respect to the indices for creditor protection and labour law, see John Armour et al, "Corporate Ownership Structure and the Evolution of Bank-
} 
mail allowed", "shares not blocked before the meeting", and "share capital required to call an extraordinary shareholder meeting", deal with different aspects of shareholders" voting power, they miss the more crucial question of the extent of this power, i.e. the issues over which the shareholders in a general meeting can exercise decision making power. ${ }^{14}$ Similarly, while the variable "cumulative voting" may be important to the extent that it seeks to measure the power of shareholders in appointment of directors, it misses the more critical question of removal of directors and the extent to which entrenchment is possible as also certain other aspects of the terms of directors, for example, their tenure, remuneration and so on. ${ }^{15}$ Further, despite using the term "anti-director index"16, the variables do not address the aspects of law relating to issues such as composition of the board, extent of director's self dealing or their disqualification at all. ${ }^{17}$

Additionally, La Porta et al's choice of variables can be criticised as suffering from a US-bias. ${ }^{18}$ On the one hand, this can be seen in the variables which have been included in the index. For instance, in the US the use of cumulative voting has been profoundly debated, ${ }^{19}$ as a result of which some US states have "opt out" and some have "opt in" provisions in their corporate laws. ${ }^{20}$ Therefore from an American perspective "cumulative voting" is perhaps a "big topic" and its regulation can be seen as a good proxy for shareholder protection in general. However, this is not the case in other countries. For example, although in France and Germany cumulative voting can

ruptcy Law: Lessons from the United Kingdom" (2002) 55 Vanderbilt Law Review 1699, 1778; B Ahlering and SF Deakin, "Labour regulation, Corporate Governance and Legal Origin: A Case of Institutional Complementarity?" (2005), 25, available at http://ssrn.com/abstract=898184 (accessed on 24 July 2006).

${ }^{14}$ For our index see infra Annex I, variable I 1.

${ }^{15}$ For our index see infra Annex I, variables I 10, 12.

${ }^{16}$ La Porta et al, supra n 7, 1123.

${ }^{17}$ For our index see infra Annex I, variables I 1.6, 13.2, 9, 10, 16.

${ }^{18}$ For a similar point see E Berglöf and EL von Thadden, "The Changing Corporate Governance Paradigm: Implications for Transition and Developing Countries" (1999), 9, available at http://ssrn.com/abstract=183708 (accessed on 24 July 2006). For more references see Cools, supra $\mathrm{n}$ $10,700-1$.

${ }^{19}$ See, eg J Gordon, "Relational Investors: A New Look at Cumulative Voting" (1994) 94 Columbia Law Review 124.

${ }^{20}$ Eg California General Corporation Law, $\S 301.5$ (a) on the one hand and Delaware General Corporation Law, § 214 on the other; see also Djankov et al, supra n 9, 28-9 (for coding Delaware law). 
be provided in the articles, ${ }^{21}$ the use of cumulative voting does not play any role and even the most elaborate and voluminous books on company law may not discuss it at all. $^{22}$

On the other hand, this can be seen from the absence of certain variables in the index. The exclusion of the law on removal of directors, in the background of the fact that the law on entrenchment of directors in the US is a subject of high criticism, ${ }^{23}$ points towards a possible US-bias. The focus on protection of shareholders from directors and the comparative disregard of the expropriation of minority shareholders by majority blockholders is another illustration. This fact has also been illustrated in a study in which a German scholar ${ }^{24}$ constructed an "alternative minority protection index, ${ }^{, 25}$ on the basis of what he believed to be more important rules for (minority) shareholder protection. It is little surprise that, on the resultant index, Germany performed better than the US.

Whilst their choice of variables indicate a possible US-bias, their coding has been subjected to some pointing criticism on account of a common-law bias. The difference between default and mandatory rules has not been sufficiently taken into account, ${ }^{26}$ so that the random reliance on mandatory law and default rules for the coding of variables across countries has been identified as part of the common-law bias. ${ }^{27}$

Finally, the trouble lies with the definitions of some of the variables. Many of the La Porta et al variables are too broad or vague. For instance, the variable "proxy voting" is unsatisfactory because probably all countries have some kind of proxy vot-

\footnotetext{
${ }^{21}$ Cools, supra n 10, 718 (for France); U Hüffer, Aktiengesetz (Munich, Beck, 6th edn. 2004), § 133 para. 33 (for Germany).

${ }^{22}$ Eg K Schmidt, Gesellschaftsrecht (Cologne, Heymanns, 3rd edn. 1997), a book with almost 2000 pages, discusses appointment of directors at 838-841 but does not mention cumulative voting even once.

${ }^{23}$ See LA Bebchuk and A Cohen, "The Costs of Entrenched Boards" (2005) 78 Journal of Financial Economics 409; see also infra Annex I, variable II 10.2.

${ }^{24}$ M Berndt, Global Differences in Corporate Governance Systems (Wiesbaden, Deutscher, Universitätsverlag, 2002), 17-18.

${ }^{25}$ He omitted "shares not blocked" and the "oppressed minorities mechanism" and instead included two new variables: "minority protection regarding authorized capital" and "minority protection regarding share repurchases."

${ }^{26}$ Better Spamann, supra n 8, 6 who distinguishes between default, mandatory, and optional rules; see also infra, Section C 2 (b).

${ }^{27}$ Eg Braendle, supra n 10, 275, has observed that "The formulation of the framework of the different criteria often seems strange. In some parts it is sufficient to score if company laws provide for an option for a right, in other parts rights have to be mandatory to acquire a point. It is obvious that this framework benefits Common Law".
} 
ing. ${ }^{28}$ Even fuzzier is the variable "oppressed minority". ${ }^{29}$ Given its description, ${ }^{30}$ it covers various substantive and procedural aspects of shareholder protection, which should have been scrutinised separately. ${ }^{31}$

\section{BUILDING A MEANINGFUL SHAREHOLDER PROTECTION INDEX}

One thing which is conspicuous in the earlier studies is the lack of reflection on the difficult topic of choosing the variables and of coding legal rules in any great detail. Very often this lack of candour gives rise to a conundrum, which leads to criticism. ${ }^{32}$

Given the problems with the existing studies, we have decided to pass over them and make a fresh start for a quantification of shareholder protection. Our new shareholder protection index traces how shareholder protection in five countries has developed over a period exceeding three decades. ${ }^{33}$ In this section we discuss how we made the choice of variables and decided how "the law" should be coded.

\section{The variables}

The new shareholder protection index of this article traces how shareholder protection in the UK, the US, Germany, France, and India has developed in the last 35 years. In this index we have endeavoured to include variables which best reflect the shareholder protection in these countries. To be sure, we do not attempt here to include nor

\footnotetext{
${ }^{28}$ See infra, Section $\mathrm{C}$ for how we have disintegrated these variables and recast them into more meaningful ones.

${ }^{29}$ Similar Spamann, supra n 8, 37.

${ }^{30}$ La Porta et al, supra n 7, 1122: "Equals one if the company law or commercial code grants minority shareholders either a judicial venue to challenge the decisions of management or of the assembly or the right to step out of the company by requiring the company to purchase their shares when they object to certain fundamental changes, such as mergers, asset dispositions, and changes in the articles of incorporation. The variable equals zero otherwise. Minority shareholders are defined as those shareholders who own $10 \%$ of share capital or less".

${ }^{31}$ For our index see infra Annex I, variables I 13.1-3, 18, II 7.1, 9.1-2.

${ }^{32}$ For instance, the lack of proper explanation and treatment of mandatory and default rules has given rise to criticism of bias, see supra, Section B.

${ }^{33}$ This is a pilot project and our intention is to expand the research to include some transition economies (and more developed and developing economies) and when we include these countries, we may modify or add to our existing list of variables to better reflect the laws on shareholder protection in these countries, if necessary.
} 
do we believe that everything that matters for shareholder protection should be considered in an index on shareholder protection. The effective protection of shareholders is linked with contract law, civil procedure, questions of legal effectiveness, as well as social, economic, and cultural differences. These aspects will be taken into account when our shareholder index will be used for a future econometric study. ${ }^{34}$ This article deliberately focuses on a diligent coding of those legal rules, which only concern shareholder protection, because, for instance, a mixed coding of shareholder rights and rule of law in one set of variables would lead to confusion rather than illumination.

The variables, which are used as proxies for shareholder protection in the index, are divided into variables which protect shareholders against directors and managers, and variables which protect (minority) shareholders against other shareholders. Furthermore, many of the variables contain sub-variables. For instance, the overall variable "power of the general meeting" consists of seven sub-variables which address different issues over which the general meeting may or may not have decision-making power, namely, amendments of articles of association, mergers and divisions, capital measures, de facto changes, dividend distributions, election of board of directors and directors" self-dealing of substantial transactions. In total, our shareholder protection index has 60 (sub-) variables whose development has been coded for the five countries. The list of these variables and a description of their coding can be found in Annex I of this article.

Some variables used in the existing literature have been disintegrated, modified and recast into more precise variables with detailed sub-variables. For instance, as observed earlier, ${ }^{35}$ the use of the variables "proxy voting" and "oppressed minority" in the previous studies is too vague. With respect to "proxy voting" it is important to distinguish between a variety of aspects, such as, who can be appointed, whether companies have to facilitate proxy voting, who bears the costs of a proxy contest, and whether the proxy rules affect communication between shareholders. ${ }^{36} \mathrm{We}$ have therefore recast it into two separate variables "anticipation of shareholder decision" and "communication with other shareholders", which are further divided into meaningful

\footnotetext{
${ }^{34}$ See supra $\mathrm{n} 6$.

${ }^{35}$ Supra, Section B.

${ }^{36}$ See infra Annex I, variables I 4.1-3, 8.2.
} 
sub-variables. ${ }^{37}$ With respect to "oppressed minority", we have first of all distinguished between substantive law for protection against mismanagement of the directors and managers and fraud on minority by or transferring of assets and profits out of firms by majority (or controlling) shareholders for their benefit. ${ }^{38}$ Moreover, there are various ways in which enforcement may operate, for instance, private-law remedies, intervention by public authorities, and disqualification are equally conceivable. We have therefore built separate sub-variables to reflect enforcement. ${ }^{39}$

In our choice of variables, we have taken account of the fact that different legal instruments can be used to achieve a similar function - the principle of "functionality". For example, there are various ways in which a decision of the general meeting may be prevented from harming minority shareholders: rules of company law may be mandatory so that the majority shareholder cannot abuse their power in the general meeting in this respect; ${ }^{40}$ company law may require approval of a public authority so that the powers of the majority shareholders are restricted; ${ }^{41}$ quorum and supermajority requirements may ensure that a significant majority has approved the decision in question; fiduciary principles may control the voting of the majority shareholder; or appraisal rights may provide the minority shareholder a way to exit the company for full compensation. ${ }^{42}$ If one of these elements is disregarded, a study which uses quantified legal variables for econometric purposes may be flawed because it does not measure shareholder protection properly. Similarly, for a leximetric study of this nature, important functional equivalents must not be ignored in order to provide a coherent and meaningful characterisation of the law.

Finally, it is crucial to consider basic insights of comparative law. A comparative lawyer must not impose one's own conceptions on a foreign legal system. The concept is summed up well in one of the leading comparative law textbooks:

\footnotetext{
${ }^{37}$ See infra Annex I, variables I 4.1-3, 8.2.

${ }^{38}$ See infra Annex I, variables I 6.1 and II 9.1.

${ }^{39}$ See infra Annex I, variables I 6.3, 16, 18.1, II 9.2.

${ }^{40}$ Opportunistic amendment hypothesis; see JN Gordon, "The Mandatory Structure of Corporate Law" (1989) 89 Columbia Law Review 1549, 1573; but see also infra, Section D 1 (c).

${ }^{41} \mathrm{Eg}$ in India, any amendment to the articles of association which has the effect of converting a public company into a private company does not have any effect unless approved by the Central Government (CA 1956, s.31 (1), proviso).

${ }^{42}$ For details see infra Annex I, variables II 1, 2, 7.1, 9.1; see also infra, Section D 1.
} 
"Europeans and Americans must be constantly aware, when studying nonWestern legal systems and cultures, that they must not approach or appraise these systems from their Western viewpoints or judge them by European or American standards. For example some Western lawyers concluded in the 1970s that China has no legal system because she has no attorneys in the American or European sense, no independent judiciary, no Codes, and, since the Cultural Revolution, no system of legal education. Yet, this is surely to judge a non-Western system by Western standards, rather like the Western visitor who assumed that there was no "proper" music played in China because he did not see any Western instruments in the Chinese concert hall he visited". ${ }^{4}$

In order to minimise any "home bias", in the construction of our variables we have therefore, looked at the OECD Principles on Corporate Governance ${ }^{44}$ the comparative literature on company law, ${ }^{45}$ as well as the laws of the countries themselves. We have also considered that there can be significant differences between developed counties and developing countries in terms of what are the crucial concerns for protection of shareholders. ${ }^{46}$ We have therefore endeavoured in our choice of variables to reflect some of the distinctive features of the Indian company law for the protection of shareholders. ${ }^{47}$

\footnotetext{
${ }^{43} \mathrm{P}$ De Cruz, Comparative Law in a changing world (London, Cavendish, 2nd edn, 1999), 223.

${ }^{44}$ OECD Principles on Corporate Governance (2004), available at http://www.oecd.org/dataoecd/32/18/31557724.pdf (accessed on 24 July 2006).

${ }^{45}$ Eg Cools, supra n 10; D Zetzsche, "Explicit and Implicit System of Corporate Control - A Convergence Theory of Shareholder Rights" (2004), available at http://ssrn.com/abstract=600722); MM Siems, Die Konvergenz der Rechtssysteme im Recht der Aktionäre (Tübungen, Mohr Siebeck, 2005).

${ }^{46}$ See, eg H Berkman, RA Cole, A Lee, and M Veeraraghavan, "The Effect of Board Composition and Ownership Structure on Firm Performance: Evidence from India", available at http://www.hhs.se/NR/rdonlyres/74CEDE8D-A06F-4D90-85EA-6645610A8B32/0/Veeraraghav-

an_Madhu.pdf (accessed on 24 July 2006), where they have observed at 47 that, "although it is critical to improve on the transparencies of business practices, especially in developing countries, it seems that it is inappropriate to merely follow the corporate governance measures prepared by other developed countries. The mere imposition of minimum proportion of independent directors on every listed company does not seem to be a panacea to the problems of corporate governance." For similar, see JR Varma, "Corporate Governance in India: Disciplining the dominant shareholder" (1997) 9 IIMB Management Review 5; R Chakrabarti, "Corporate Governance in India - Evolution and Challenges" (2005), available at http://ssrn.com/abstract=649857 (accessed on 24 July 2006); T Khanna, "Business groups and social welfare in emerging markets: Existing evidence and unanswered questions" (2000) 44 European Economic Review 748.

${ }^{47}$ See eg infra Annex I, variables I 18, II 7 (3).
} 


\section{The coding}

Attributing and comparing legal differences by numbers is contrary to the traditional way of doing comparative law. The use of a quantitative methodology to account for variations across legal systems is inevitably reductive, and, as such, may be subjected to some searching criticisms. ${ }^{48}$ However, we believe that with a cautious approach, it has the potential to open new vistas of research in the area of comparative law and as such should not be shunned. In fact, this article in Section D provides an illustration of interesting possibilities that diligent quantification of legal rules provides for comparing variations across time series and across legal systems.

The coding of legal rules is difficult, because law is not a "thing" which can be quantified as easily as money, cars, or persons. In this exercise, it is often easier to define a variable, we realised, than to actually ascertain the law and code it by assigning it a number. It is sometimes a matter of legal judgment. ${ }^{49}$ The way we have sought to tackle this issue, is to ensure that lawyers trained in the jurisdictions either did the actual coding or we have sought such experts to validate our coding. But as is common knowledge, often lawyers even from the same jurisdiction disagree on the position of law. We believe that transparency is a solution to this problem. Being constrained by space here, we have included few variables as illustration, ${ }^{50}$ but we would be publishing on the internet both our coding and our explanatory notes, shortly.

In this interesting and often treacherous journey through the legal systems of five different countries, we encountered some difficult patches, for instance, where our path reached a fork and we had to chose one of the directions or where our path was hazy or not completely clear: throughout this exercise though, we have been guided by the underlying principles of "functionality" and "transparency".

\section{(a) Areas of law}

Our coding concerns shareholder protection only - as opposed to investor protection in general. We started by looking at company law. However, in some cases it was

\footnotetext{
${ }^{48}$ See MM Siems, "Numerical Comparative Law - Do We Need Statistical Evidence in Order to Reduce Complexity?" (2005) 13 Cardozo Journal of International and Comparative Law 521.

${ }^{49}$ For instance, the variables I. 13, II. 17 (see infra Annex I).

${ }^{50}$ Infra Annex II.
} 
necessary to take securities law into account, because certain aspects of the protection of shareholders from directors and majority shareholders are sometimes addressed in securities law. An example is the US securities law on the appointment of proxy, because its regulation is to a large extent regulated in federal securities law. ${ }^{51}$ Functionally it does not make a difference which area of law addresses a particular topic. We may mention here that while coding we have considered law as it applies to the listed companies $^{52}$ which also goes to explain why we find provisions relevant for some of the variables in securities law.

Because of our focus on rules which address the protection of "shareholders as such" and not investors in general, most parts of securities law have not been taken into account. For instance, the rules on insider trading, on public disclosure and transparency of financial information, as well as accounting requirements are not coded in detail. ${ }^{53}$ The prohibition of insider trading aims at protection of investors and capital markets in general but not specifically at the protection of "shareholders as such". ${ }^{54}$ The disclosure of financial information and accounting requirements are general topics which also target the protection of bondholders, other lenders, financial markets, and perhaps even the society as a whole. Thus, these legal topics we believe, should be addressed in separate indices. ${ }^{55}$

\section{(b) Mandatory as well as default rules}

One of the difficult questions that we had to decide was - to what extent we should code not mandatory law alone but default rules as well. In Part I of our variables (infra Annex I) no distinction has been made between default and mandatory law. Since

\footnotetext{
${ }^{51}$ SEC Regulation 14a; SEC Rules $14 \mathrm{a}-1$ to $14 \mathrm{~b}-2$.

${ }^{52}$ This is so because the economic data that would be combined and tested in the further econometric study for which these indices form the basis (see supra n 6 and 38) is available with respect to listed companies.

${ }^{53}$ But see infra Annex I, variables I 7, 10.2 and II 8.

${ }^{54}$ Indirectly, however, shareholders may be protected; see on the divisive nature of the prohibition of insider trading: H Manne, Insider Trading and the Stock Market (New York, The Free Press, 1966); R Romano, The Genius of American Corporate Law (Washington, AEI Press, 1993), 103; VF Calaba, "The Insiders: A Look at The Comprehensive and Potentially Unnecessary Regulatory Approaches to Insider Trading in Germany and the United States" (2001) 23 Loyola of Los Angeles International and Comparative Law Journal 457, 474.

${ }^{55}$ Disclosure is also addressed separately in R La Porta et al, What Works in Securities Law?, (2006) 61 Journal of Finance 1; some aspects of disclosure are also examined in Djankov et al, supra $\mathrm{n} 9$.
} 
these variables address the protection of shareholders against directors and managers, the thinking is that the shareholders can together prevent deviation from a default rule which aims at their protection. Conversely, with respect to the protection of shareholders against major shareholders (Part II of our variables), there are some variables which only code mandatory law. ${ }^{56}$ The reason for this is the principle of functionality because mandatory rules can be an instrument to protect minority shareholders against tunnelling of the majority. ${ }^{57}$ Furthermore, three (sub-) variables address the question of whether minority shareholders can prevent the majority of shareholders from opting out of the protection of shareholders against directors and managers. ${ }^{58}$ This is important if the board can control the shareholder meeting or if the majority shareholder and board act together, because in these cases the protection against board and other shareholders is rendered interchangeable.

As far as default rules are concerned, the corporate governance codes and in the case of UK and India the Table A of British and Indian company law have also been taken into account. ${ }^{59}$ Since all companies in these countries need articles of association, the Table A regulations operate as a "model off the shelf". Likewise, for listed companies corporate governance codes can be at least as important as default rules ${ }^{60}$ because non-compliance of corporate governance codes may severely hinder corporate finance and thus the very purpose of being listed may be impaired. Thus, at least in developed countries compliance with corporate governance codes is the rule. ${ }^{61}$

\footnotetext{
${ }^{56}$ Specifically, variables II 3.2-3, 10; the law on variables II 6, 7.2-3, 8 is also mandatory in all countries.

${ }^{57}$ See already supra, Section II.

${ }^{58}$ See infra Annex I, variables II 9.1and 2.

${ }^{59}$ For instance while coding the variables I 4.6, 9.2-3, the Table A and corporate governance codes have been taken into account. See also infra Annex I, variable I 17.

${ }^{60}$ In the case of India, the provisions in relation to corporate governance were introduced in the Listing Agreement (Clause 49 since 2000), which has statutory force since 1995; see (c) and infra $\mathrm{n} 77$.

${ }^{61}$ For instance for the UK see: SR Arcot and VG Bruno, "In Letter not in Spirit: An Analysis of Corporate Governance in the UK" (2006), available at http://fmg.lse.ac.uk/ arcot/CGPaper1.pdf (accessed on 24 July 2006); for Germany: A von Werder, T Talaulicar, and GL Kolat, "Compliance with the German Corporate Governance Code: an empirical analysis of the compliance statements by German listed companies" (2005) 13 Corporate Governance 178; for France: S Hebert, "Corporate Governance French Style" (2004) Journal of Business Law 656, n 47; contra G Rossi, "Do Good Governance Recommendations Change the Rules for the Board of Directors?", in KJ Hopt and E Wymeersch (eds), Capital Markets and Company Law (Oxford University Press, 2003), 493 (effects of corporate governance codes are part of a "new mythodology of corporate law").
} 
We also coded the British City Code on Takeovers and Mergers. Although it is not statutory law and legal sanctions are often not available, compliance is the rule. ${ }^{62}$ Our index takes the City Code into account to provide a meaningful picture of how shareholders are protected in case of takeovers in the UK.

\section{(c) Non-uniform law and listing rules}

For federal states coding may lead to a problem if the law on shareholder protection is not regulated in a uniform way. From amongst our panel countries, this was a concern with respect to the US alone. ${ }^{63}$ More than half a million business entities have their legal home in Delaware including more than $50 \%$ of all U.S. publicly-traded companies and $58 \%$ of the Fortune $500 .{ }^{64}$ We have therefore decided to look at the Delaware General Corporation Law (DGCL).

A related problem exists where there is more than one stock exchange in one country. Here we have chosen the dominant stock exchange, for instance the NYSE and considered its rules while coding for the US.

Furthermore, it could be problematic that listing rules are sometimes based on statutory law and sometimes on self-regulation of the stock exchange. For example, in the UK prior to 1985 the listing rules were only the LSE's own private requirements. ${ }^{65}$ Since then the listing rules have had a statutory basis, and, moreover, in 2000 the Financial Services and Markets Act shifted the competence for the listing rules from the LSE to the UK Listing Authority, a component of the Financial Services Authority. Similarly, in India the Listing Agreement Form has had statutory force only since 1995. ${ }^{66}$ However, from a functional perspective these differences do not matter. Since even in the past listed companies could not escape the listing requirements, these selfregulatory rules have also been taken into account for our coding.

\footnotetext{
${ }^{62}$ See generally J Armour and DA Skeel, “A Ocean of Difference on Takeover Regulation”, in J Grant (ed.), European Takeovers: The Art of Acquisitions (London, Euromoney Books, forthcoming).

${ }^{63}$ Company law is uniform in Germany, India, and the UK.

${ }^{64}$ See http://www.delaware.gov/ sub "division of corporations" (accessed on 24 July 2006).

65 See JL Powell, Issues and Offers of Company Securities: The New Regime (London, Sweet and Maxwell, 1988), paras. 2-3, 5-11.

${ }^{66}$ See the amended s. 21 of the Securities Contract (Regulation) Act 1956.
} 


\section{(d) Statutory and case law}

A particular legal rule can be based on statutory law or case law. With respect to case law, a doctrinal approach may be put forward that in common-law countries case law is regarded as a source of law, whereas in civil law countries court decisions are merely seen as a clarification of the existing law. ${ }^{67}$ However, our index has not distinguished in this respect. Despite the different starting point, both in common-law and in civil-law countries, court decisions can bring about an effect which is as important as a statutory provision. ${ }^{68}$ Thus, following a functional approach we have taken into account statutory law as well as court decisions and the legal changes brought about by them.

Statutory law has been coded in the year in which it comes into force and case law has been coded it in the year in which it is delivered and reported. There are certain tricky questions like statutes passed but not yet in force or decisions either unpublished or expected, ${ }^{69}$ but these are some aspects of the law that cannot be considered for coding.

\section{(e) Unweighted variables}

Another issue that we considered while coding the variables for this study, was that of weighting of variables. ${ }^{70}$ It is conceivable that not all of our variables will have the same significance in all the countries. Naturally, geo-political considerations, economic concerns, or cultural differences may mean that, while some of the measures coded here may be more important in some countries, they may not be so important in

\footnotetext{
${ }^{67}$ See, eg HP Glenn, Legal Traditions of the World (Oxford Univeristy Press, 2nd edn, 2004), 177, 237.

${ }^{68}$ See, eg B Markesinis, Foreign Law and Comparative Methodology: A Subject and a Thesis (Oxford, Hart, 1997); B Markesinis, Always on the Same Path: Essays on Foreign Law and Comparative Methodology, Volume 2, (Oxford: Hart, 2001).

${ }^{69}$ For this problem see S Bhagat and R Romano, "Empirical Studies of Corporate Law" (2005), 7, available at http://ssrn.com/abstract=728103 (accessed on 24 July 2006) and forthcoming in AM Polinsky and S Shavell, Handbook of Law and Economics.

${ }^{70}$ The previous studies have received criticism on this count: see Braendle, supra n 10, 276 (on the shareholder protection index); MM Siems, "What Does Not Work in Comparing Securities Law", (2005) International Company and Commercial Law Review 300, 305 (on the securities law index); B Ahlering and SF Deakin, supra n 13, 19 (on the labour law index). But as suggested in Ahlering and Deakin, ibid, "One possible answer to this objection is that weightings for cross-national indices are extremely difficult to determine, and that an unweighted index might be less biased than one based on subjective attempts at weighting."
} 
others. However, having considered the option of weighting the variables, which poses a difficult question of how much weight to be given to each variable in each country - which invariably would have involved subjective elements, we decided in favour of unweighted measures. It is arguable therefore that our index does not fully capture the comparative shareholder protection. In defence we yet again rely on our functional approach, which has meant that we have taken into account the existence of functional equivalents across jurisdictions. This explains the large number of variables! To be sure, we do not claim that the variables coded are the only or maximum or even optimum rules for protection of shareholders: what we have attempted here is to choose and code for variables that are capable of acting as proxies for the protection of shareholders in these countries.

\section{(f) Non-binary coding}

Finally, it had to be decided whether to use binary coding only $(0,1)$ or non-binary numbers too $(1 / 2,1 / 3,1 / 4,2 / 3,5 / 8$ etc. $)$. Against the use of binary coding in some of the previous studies it was argued that binary evaluation of legal systems according to " 0 or 1 " is a very simplified method to judge the extent of shareholder protection. ${ }^{71}$ However, one can equally criticise the use of non-binary coding: whereas the use of "0" and " 1 " can easily be translated as "yes" and "no", the non-binary use of numbers for law can appear to be arbitrary. ${ }^{72}$

Here, we decided to use binary as well as non-binary numbers because it is not always possible to translate legal rules into "yes"-"no" questions. For instance, the statutory law may be ambiguous, or judges may disagree. If no clearly predominant opinion exists, it is more accurate to code a variable as " $1 / 2$ " or some other intermediary score than to randomly decide that either the " 1 " or the " 0 " score is more persuasive. Furthermore, non-binary coding has the advantage that more information can be included in a single variable. For example, according to our index, the variable which measures the information which shareholders get in case of amendments of the articles of association "equals 1 if the exact wording is sent in advance ("push-system"),

\footnotetext{
${ }^{71}$ Braendle, supra n 10, 264, 276 on La Porta et al, supra n 7; similar T Baums an K Scott, "Taking Shareholder Protection Seriously? Corporate Governance in the United States and Germany" (2003), 15, available at http://ssrn.com/abstract=473185 (accessed on 24 July 2006).

${ }^{72}$ See Siems, supra n 70, 305 on Djankov et al, supra $n 9$.
} 
equals 0.5 if the shareholders have to request it ("pull-system"), and equals 0 otherwise." 73 Here it might be objected that there is no reason why a "pull-system" is exactly half as good as "pull-system". This is indeed a fair point, and non-binary coding is undeniably to some extent a matter of judgment. However, law is complex and we believe that a faithful coding should also reflect this very feature of law. Non-binary coding can therefore lead to more meaningful results than the mere use of " 0 " and " 1 ".

\section{LEXIMETRICS: THE RESULTS}

Using our shareholder protection index, various interesting questions can be addressed: For instance, it can be asked which country scores the maximum on our shareholder protection index; how much these legal systems have changed over the years; whether differences follow the distinction into civil-law and common-law countries; and whether the laws of the five countries are converging or diverging. In this Section we consider some of these questions using graphical representations of values of the five indices that we constructed for our panel countries.

\section{General shareholder protection aggregate}

At the outset, we simply aggregate all 60 (sub-) variables from our shareholder protection index for each of the countries and represent it graphically. The resultant graph is shown in Figure 1:

\footnotetext{
${ }^{73}$ Infra Annex I, variable I 5.1.
} 


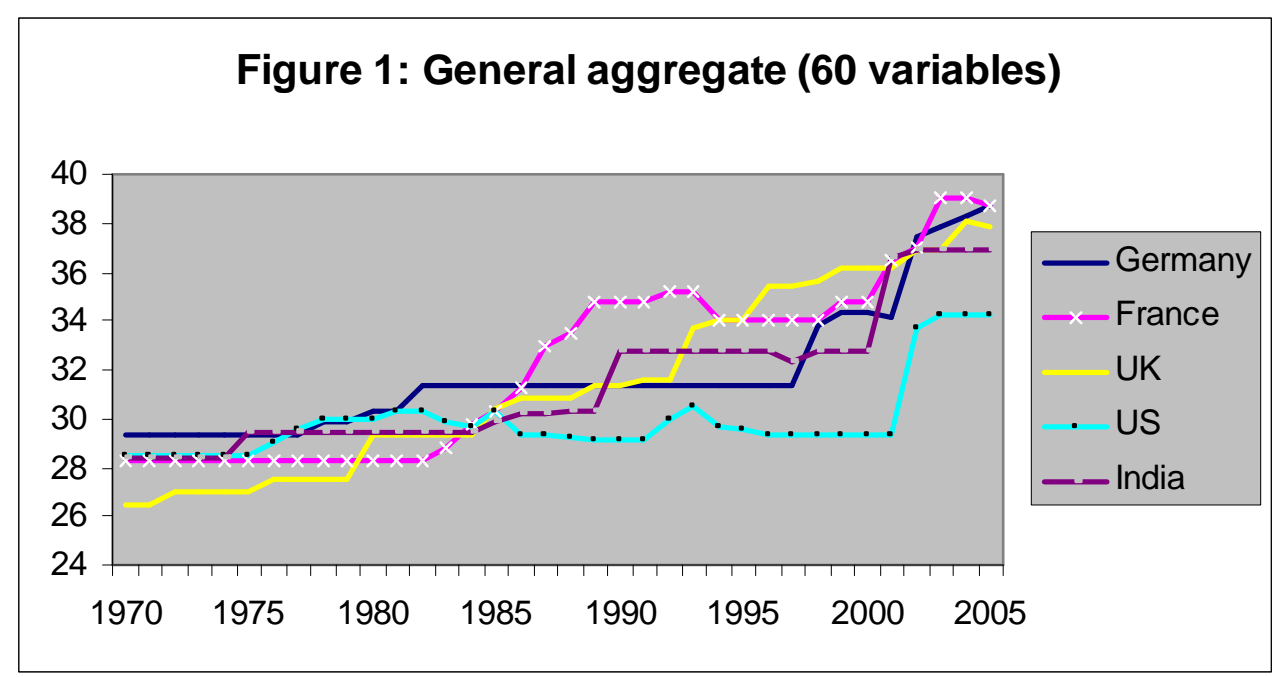

(a) The five curves in Figure 1 demonstrate some common features. First of all, in general, all of them exhibit an upward movement, which means that the aggregate value of the indices increased with time. Thus, legal shareholder protection has been improving in the last three decades. In particular there is an enhancement in shareholder protection in the last five years, which given the recent attention to good corporate governance is hardly surprising. Secondly, at times the curves climbed down a few points. This phenomenon, which took place particularly in the 1980s and 90s, can be explained by the desire to make the law more flexible as it is believed to be more business friendly. For instance, in some countries the issuing of stock options without approval of the general meeting, the exclusion of pre-emptive rights, or the squeeze out of minority shareholders was introduced or became easier. ${ }^{74}$ Thirdly, most curves have plateaus and steps. Law often does not change gradually. On the one hand, there may be years when a particular part of the law, such as the protection of shareholders, does not change at all. On the other, a law reform or a bundle of court decisions, may lead to amendments of various aspects of shareholder protection resulting in a sharp rise in the value of an index in a short while.

(b) In addition to the common features above, the curve for each country has specific features of its own. In particular, regarding the UK law one can see a fairly constant improvement of shareholder protection. The steps in 1980, 1985 and in the 1990s

\footnotetext{
${ }^{74}$ Exchange Act Release No. 34-36356, 60 Fed. Reg. 53,832 (1995); Gesetz für kleine Aktiengesellschaften und zur Deregulierung des Aktienrechts, 2. 8. 1994, BGBl. I 1961; Loi no 1993-1444 du 31 décembre 1993.
} 
were caused mainly by the company law reforms and the codes of best practice. ${ }^{75}$ There are also relatively smaller steps which were, for example, the result of the strengthening case law on directors" duties. ${ }^{76}$ The US curve looks quite different. As we have coded Delaware corporate law, which is famous for its "light approach" in regulating the internal affairs of companies, ${ }^{77}$ it is no surprise that for most part of the time-series the US values are lower than the ones of the other countries. To be sure, there were frequent changes in the Delaware General Corporation $\mathrm{Law}^{78}$ as well as important decisions of the Delaware courts. ${ }^{79}$ However, these events have not led to major reorientations of Delaware's law on shareholder protection. The steep rise in 2002 reflects the changes brought about by the Sarbanes Oxley Act 2002 which led to a strengthening of shareholder protection. ${ }^{80}$

By contrast, French shareholder protection law shows a remarkable improvement in the late $80 \mathrm{~s}$ and early $90 \mathrm{~s},{ }^{81}$ and in these years it was, perhaps surprisingly, clearly more shareholder friendly than the law of the other countries. Then, the curve climbed down a few points during mid-90s, because of the belief that French company law should become more flexible. ${ }^{82}$ Similar to the other curves, the French curve again follows an upward movement since $1999 .{ }^{83}$ Only in this respect, the German situation

\footnotetext{
${ }^{75}$ Cadbury Committee, Code of Best Practice (1992, applied since 1993); Greenbury Committee, Code of Best Practice (1995, applied since 1996); Hampel Committee, Combined Code of Best Practice (1998, applied since June 1998).

${ }^{76}$ Norman v Theodore Goddard [1991] B.C.L.C 1027; Re D’Jan of London [1994] 1 BCLC 561; Bishopsgate Investment Management Ltd. v Maxwell (No. 2) [1994] 1 All ER 261; Re Barings plc (No.5) [1999] 1 BCLC 433, esp. 486-489; Re Landhurst Leasing plc [1999] 1 BCLC 286.

${ }^{77}$ Critics call this a "race to the bottom"; see WL Cary, "Federalism and Corporate Law: Reflections Upon Delaware" (1974) 83 Yale Law Journal 663; others emphasise its efficiency; see Romano, supra n 54, 14.

${ }^{78}$ Usually, the Delaware General Corporation Law is amended every year.

${ }^{79}$ Eg on takeover law Unocal Corp. v Mesa Petroleum, Co., 493 A.2d 946 (Del. Supr. 1985); Moran v Household Int'l, Inc., 500 A.2d 1346, 1350 (Del. 1985); Revlon, Inc. v MacAndrews \& Forbes Holdings, Inc., 506 A.2d 173 (Del. Supr 1986); Paramount Communications, Inc. v Time, Inc., 1989 WL 79880 (Del Ch. 1989); Paramount Communications, Inc. v QVC Network, Inc., 637 A.2d 34 (Del. Ch. 1994); Unitrin, Inc., v American General Corp., 651 A.2d 1361 (Del. 1995).

${ }^{80}$ Sarbanes-Oxley Act (Public Company Accounting Reform and Investor Protection Act) (USA) of 30.07.2002, Pub. L. No. 107-204, 116 Stat. 745; eg with respect to committees, independence requirements, corporate governance guidelines, and disqualification.

${ }^{81}$ Eg by Loi no 83-3 du 3 janvier 1983; Loi no 84-148 du 1er mars 1984; Loi no 85-98 du janvier 1985; Décret no 86-584 du 14 mars 1986; Loi no. 87-416 du 17 juin 1987; Loi no 88-17 du 5 janvier 1988; Loi 89-531 du 2 août 1989; Arrête du 15 mai 1992.

${ }^{82}$ Loi no 94-126 du 11 février; Loi 94-679 du 8 août 1994; Loi no 1993-1444 du 31 décembre 1993.

${ }^{83}$ Caused by Code de Commerce 2000; Loi no 2001-420 du 15 mai 2001; Décret no 2002-803 du 3 mai 2002; Loi no 2003-706 du 1er août 2003; Loi no. 2005-842 du 24 juilliet 2005; also Principes de gou-
} 
is similar to the French. Apart from the changes in the late 1990 s and early $2000,{ }^{84}$ the German law on shareholder protection has been relatively stable. An explanation could be that some of the European company law directives of the 70s and early 80 s were based on German company law. ${ }^{85}$ Furthermore, in the 80 s and early 90 s other legal topics such as the reform proposals on the German contract law and insolvency law, and problems related to the German unification were at the fore.

Lastly, the Indian curve also shows phases of relative stability ${ }^{86}$ and a giant leap in 2001. Apart from the developments in the takeover $\operatorname{law}^{87}$ the shareholder protection law during the 90 s remained largely unchanged. ${ }^{88}$ There could be at least two possible explanations for this: first, the Indian economy was opening up so that there were other areas of law that were deemed to be more crucial for the process of liberalisation, which therefore, deserved more attention of the legislators. ${ }^{89}$ Secondly, with the onset of liberalisation the stock market capitalisation rose up, shareholding became relatively more dispersed (and included foreign investors) so that the issues concerning corporate governance came to the fore and really gained significance only after this initial period of stock market growth. The series of corporate scandals that followed the initial period of liberalisation further pressed the need for better corporate governance. ${ }^{90}$ This culminated into adoption of improved corporate governance provi-

vernement d'entreprise résultant de la consolidation des rapports conjoints de l'AFEP et du MEDEF (2003).

${ }^{84}$ Gesetz zur Namensaktie and zur Erleichterung der Stimmrechtsausübung (NaStraG), 18.1.2001, BGBl. I 123; Unternehmensübernahme-Regelungsgesetz, 20.12.2001, BGBl. I 3822; Viertes Finanzmarktförderungsgesetz, 21.6.2002, BGBl. I 2010; Transparenz- und Publizitätsgesetz (TransPuG), 19.7.2002, BGBl. I 2681; Gesetz zur Unternehmensintegrität und Modernisierung des Anfechtungsrechts (UMAG), 22.9.2005, BGBl. I 2802; Gesetz über die Offenlegung der Vorstandsvergütungen (VorstOG), 3.8.2005, BGBl. I 2267

${ }^{85}$ Eg Second Council Directive 77/91/EEC; Third Council Directive 78/855/EEC; Sixth Council Directive 82/891/EEC.

${ }^{86}$ During most of the mid-1990s and also in the 1970s and early 1980s

${ }^{87}$ With the introduction of Clause 40A and 40B of Listing Agreement in 1990 and then the introduction of SEBI (Substantial Acquisition of Shares and Takeovers) Regulations of 1994 and 1997.

${ }^{88}$ This was in fact the period of most dramatic changes in India with the onset of liberalisation. However the concentration on shareholder protection is probably too narrow to adequately capture the changes taking place in corporate finance in developing countries; A Singh, A Singh, and B Weisse, "Corporate Governance, Competition, the New International Financial Architecture and Large Corporations in Emerging Markets" (2002), 53, available at http://www.cbr.cam.ac.uk/pdf/WP250.pdf (accessed on 24 July 2006).

${ }^{89}$ For instance, the liberalisation of the internal regulatory framework, reduction in tariffs, adoption of appropriate exchange rate, permitting foreign investment to play a significant role in the economy.

${ }^{90}$ See O Goswami, "India: The Tide Gradually Rises", in C Oman (ed.) Corporate Governance in Development (Paris: OECD, 2003), 105 for a discussion on these early scandals. 
sions, which is reflected by the gain of significant points around $2001 .^{91}$ What emerges therefore, from the Indian experience, is a pattern where the law follows rather than leads investor expectations as well as economic development. ${ }^{92}$

(c) In analysing these differences and developments one cannot help wondering whether French law really offers "better" shareholder protection than US law, and if so, whether investors should redirect their capital.

The clear answer is that this implication cannot be drawn. First of all, it has to be reminded that we coded the law on shareholder protection alone, and have not considered other aspects such as financial disclosure, the rule of law or socio-economic attitudes, which may also be related to shareholder protection. ${ }^{93}$

Secondly, the extent to and the manner in which shareholders should be protected can vary in time dependent on a number of factors - such as the extent of blockholder control or dispersed share ownership structures, the level of development of legal and economic institutions etc. Thus, not the absolute score but the legal adaptability of a particular legal system may be more important. ${ }^{94}$ In this respect it is often said that Delaware has a particular advantage because of its judiciary. ${ }^{95}$ However, legal adaptability is not restricted to case law alone, because, for example, the frequent changes of French company law in the 80 s were mainly caused by reforms of the codified law. ${ }^{96}$

Thirdly, more shareholder protection need not necessarily be better. Company law has to balance between different interests so that not a "maximum" but an "optimum" of shareholder protection has to be found. ${ }^{97}$ For example, whilst the value of the

\footnotetext{
${ }^{91}$ As a result of the introduction of Clause 49 to the Listing Agreement and also amendments to the Companies Act 1956 itself. Although Clause 49 was introduced by the Securities and Exchange Board of India (SEBI) in 2000, the changes brought about by it have been coded from 2001, because compliance with the clause was required in a phased manner depending on the size of the listed companies beginning from March 2001.

${ }^{92}$ For instance see Singh et al, supra n 88, 20; a similar view has also been put forward in relation to the development of securities markets in the US and UK, see Coffee, supra n 13, 77; see also BR Cheffins, "Does Law Matter? The Separation of Ownership and Control in the United Kingdom", (2001) 30 Journal of Legal Studies 459; but for a different view see La Porta et al, supra n 56.

${ }^{93}$ See supra, Section C 2 (a).

${ }^{94}$ See generally MM Siems, "Legal Adaptability in Elbonia” (2006), available at http://ssrn.com/abstract $=899507$ (accessed on 24 July 2006).

${ }^{95}$ Romano, supra n 54, 37.

${ }^{96}$ See supra n. 81.

${ }^{97}$ Cf for related lines of reasoning I Anabtawi, "Some Skepticism about Increasing Shareholder Power" (2006) 53 UCLA Law Review 561; SM Bainbridge, "The Case for Limited Shareholder Voting Rights"
} 
shareholder protection index for the US has increased considerably in the recent years due to the Sarbanes Oxley Act, the changes brought about by the Act and its implications have received criticism and some scepticism on whether it would actually mean an improvement in corporate governance. ${ }^{98}$

A related point, fourthly, is that some of the variables in our index have been included and coded because they are relevant for shareholder protection but they may actually be unsatisfactory because they excessively restrict companies. ${ }^{99}$ For example, mandatory company law protects minority shareholders, because it prevents the majority from changing the articles in order to exploit the minority. ${ }^{100}$ However, its inflexibility may in the end not only be a problem for the majority of the shareholders but may also harm the company in general and thus the shareholders as a whole. ${ }^{101}$ Another example is the control of appointment of managers by government or public authority. ${ }^{102}$ In a country like India where many companies have traditionally been family dominated enterprises, the majority shareholders would typically fill managerial places with their own kinship. Therefore, control over appointment of managers by the government in the interest of the shareholders can seem to be protective of the shareholders. Yet, this control mechanism can lead to delays and foster rent-seeking behaviour that could hinder business and be harmful to shareholders as a whole. ${ }^{103}$

(2006) 53 UCLA Law Review 601; LA Stout, "Do Antitakeover Defenses Decrease Shareholder Wealth? The Ex Post/Ex Ante Valuation Problem”, (2002) 55 Stanford Law Review 101.

${ }^{98}$ See eg R Romano, The Sarbanes-Oxley Act and the Making of Quack Corporate Governance, (2005) 114 Yale Law Journal 1521.

${ }^{99}$ Apart from the examples mentioned in the text, one may, eg criticise the inflexibility of quorum and supermajority requirements (infra Annex I, variables II 1 and 2) and the deterring effect of the mandatory bid (infra Annex I, variable II 3.2) on takeovers (on this topic see, eg L Enriques, "The Mandatory Bid Rule in the Takeover Directive: Harmonization Without Foundation?" (2004) European Company and Financial Law Review 440).

${ }^{100}$ See supra, Section C 1, and infra Annex I, variable II 10; the aggregate scores for this variable in our data for 2005 are Germany: 4 points; France: 3 points; India: 2.5 points; UK: 2 points; US: 1.5 points.

101 Reference can also be made to the "nexus-of-contracts" conception of the company; see eg F Easterbrook and DR Fischel, The Economic Structure of Corporate Law (Cambridge, Mass., Harvard University Press, 1991).

${ }^{102}$ See infra Annex I, variable I 18.2.

${ }^{103}$ For instance, in India the requirement of prior authorisation of the government for appointment of managerial personnel has been relaxed since 1988, with the introduction of Schedule XIII (as amended from time to time), admittedly to make the law more flexible and to give companies more freedom in this respect. 


\section{Aggregates of specific groups of variables}

In order to get a more meaningful picture than that provided by the general aggregate above it can be useful to deconstruct our index of 60 (sub-)variables and look at aggregates of specific groups of variables. One way of doing this is to look at the variables which protect shareholders against board and managers on the one hand, and the variables that protect minority shareholders against majority shareholders on the other. ${ }^{104}$ The result of this can be seen in Figures 2 and 3 below: ${ }^{105}$
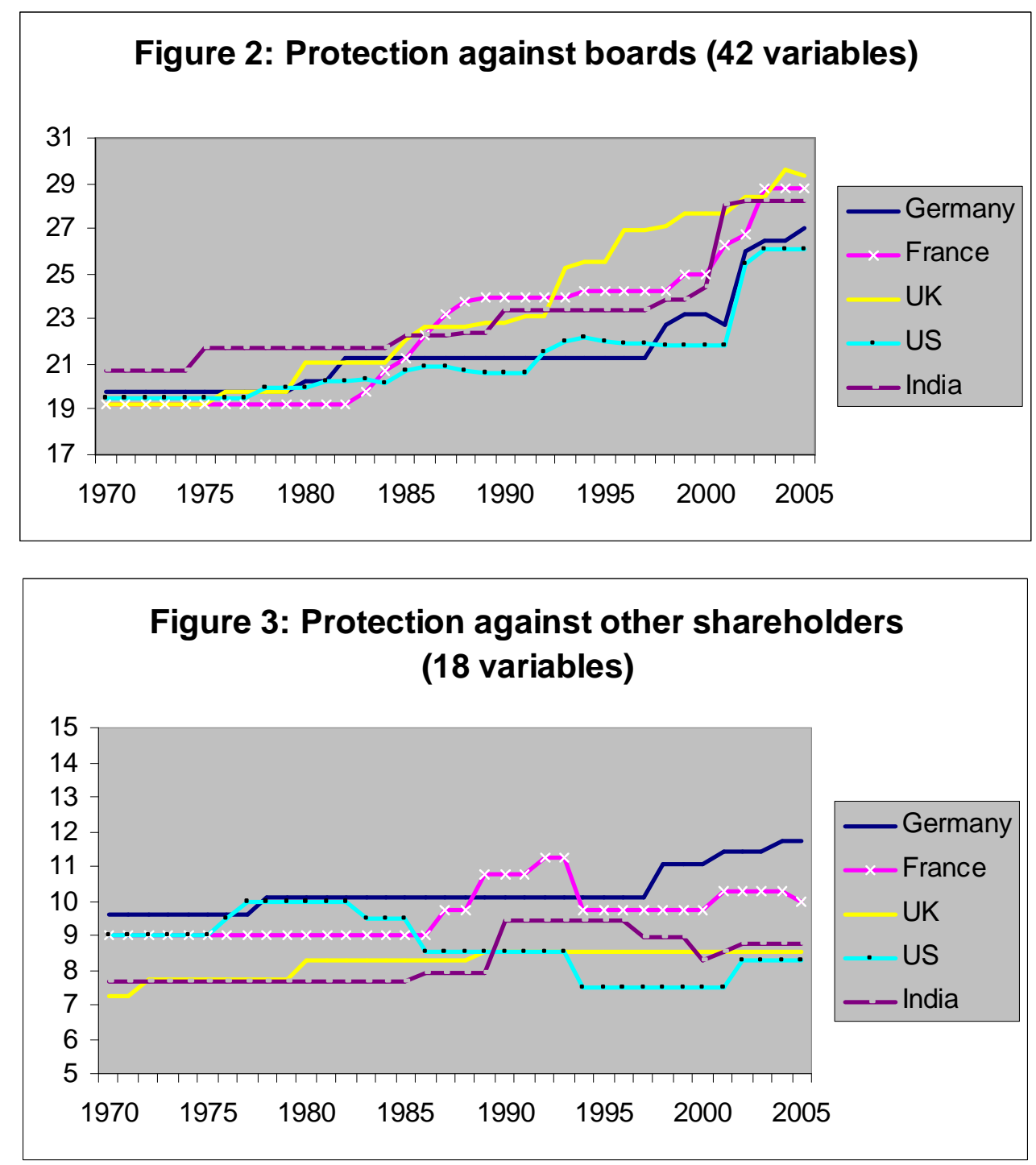

\footnotetext{
${ }^{104}$ See infra Annex I, variables I and II.

105 The difference in the number of variables in Figures 2 and 3 (42 v 18) is the consequence of the higher complexity of the law which provides protection against board and managers and the fact that in recent times there has been a focus on this aspect of shareholders protection.
} 
First, it is conspicuous from Figures 2 and 3 that in all the countries the protection of shareholders against directors and managers has increased considerably, whereas the protection against other shareholders has not changed much. ${ }^{106}$ One way to explain this could be that the growing importance of capital markets leads to more dispersed shareholder ownership ${ }^{107}$ and this increased shareholder base may exert pressure to improve primarily the protection of shareholders against directors and managers. Secondly, distinguishing between different countries, the protection against other shareholders is more important in blockholder countries, because here there is the danger that major shareholders exploit the minority. Given the fact that blockholders often dominate public companies in India, France, and Germany, this could be the reason why these countries perform better in Figure 3 than the UK and the US, where dispersed shareholder ownership is more common. ${ }^{108}$ Thirdly, however, Figure 2 does not show similar differences between blockholder and dispersed ownership countries. This is noteworthy because it refutes the argument that there is an indispensable link between dispersed shareholder ownership and strong shareholder protection. ${ }^{109}$ To be sure this does not mean that shareholder protection does not matter at all in this respect, because a certain level of shareholder protection can still be a necessary (but not sufficient) precondition for the separation of ownership and control through dispersed holdings. ${ }^{110}$

\section{Convergence and divergence of the law}

At first glance, just looking at Figure 1 (see supra 1.), one may get the impression that in 2001 the laws of the UK, India, France, and Germany were identical because all four countries have approximately the same score of 38 out of 60 variables. This would, however, not be a fair assessment. As Figure 1 simply shows the aggregate of

\footnotetext{
${ }^{106}$ Barring the US curve, which loses a few points in the 1980s and 90s in particular because of introduction of flexibility in issuance of shares with varying voting rights and in exclusion of liability for breach of duty of care (variables II 3.2-3, 10.1).

${ }^{107}$ For details see Siems, supra n 45, 368-376.

${ }^{108}$ On differences in shareholder structure see, eg F Barca and M Becht (eds), The Control of Corporate Europe (Oxford University Press, 2001); L Van den Berghe, Corporate Governance in a Globalising World: Convergence or Divergence? A European Perspective (Boston: Kluwer Academic Publishers, 2002), 34.

${ }^{109}$ La Porta et al, supra $\mathrm{n} 7$.

${ }^{110}$ Similar MJ Roe, Corporate Law's Limits, (2002) 31 Journal of Legal Studies 233.
} 
all the variables, it is perfectly possible and indeed is the case that, different variables have led to similar scores for the UK, India, France, and Germany. Therefore to highlight the differences between the countries with a view to identifying trends of convergence or divergence we have calculated the differences between each variable in the law of a particular legal system and the same variable in the law of the other countries. Subsequently, the absolute values of these differences have been added together and represented graphically in Figures 4 and 5 below. For example, Figure 4 displays four curves that represent the difference between French law and each of the other panel countries. The lower the score of a country, the more similar is the law of that country to French law. Thus, a country would, for instance, produce the score of " 0 " if it were completely identical to French law, and it would produce the score of "60" if it were completely different to it.
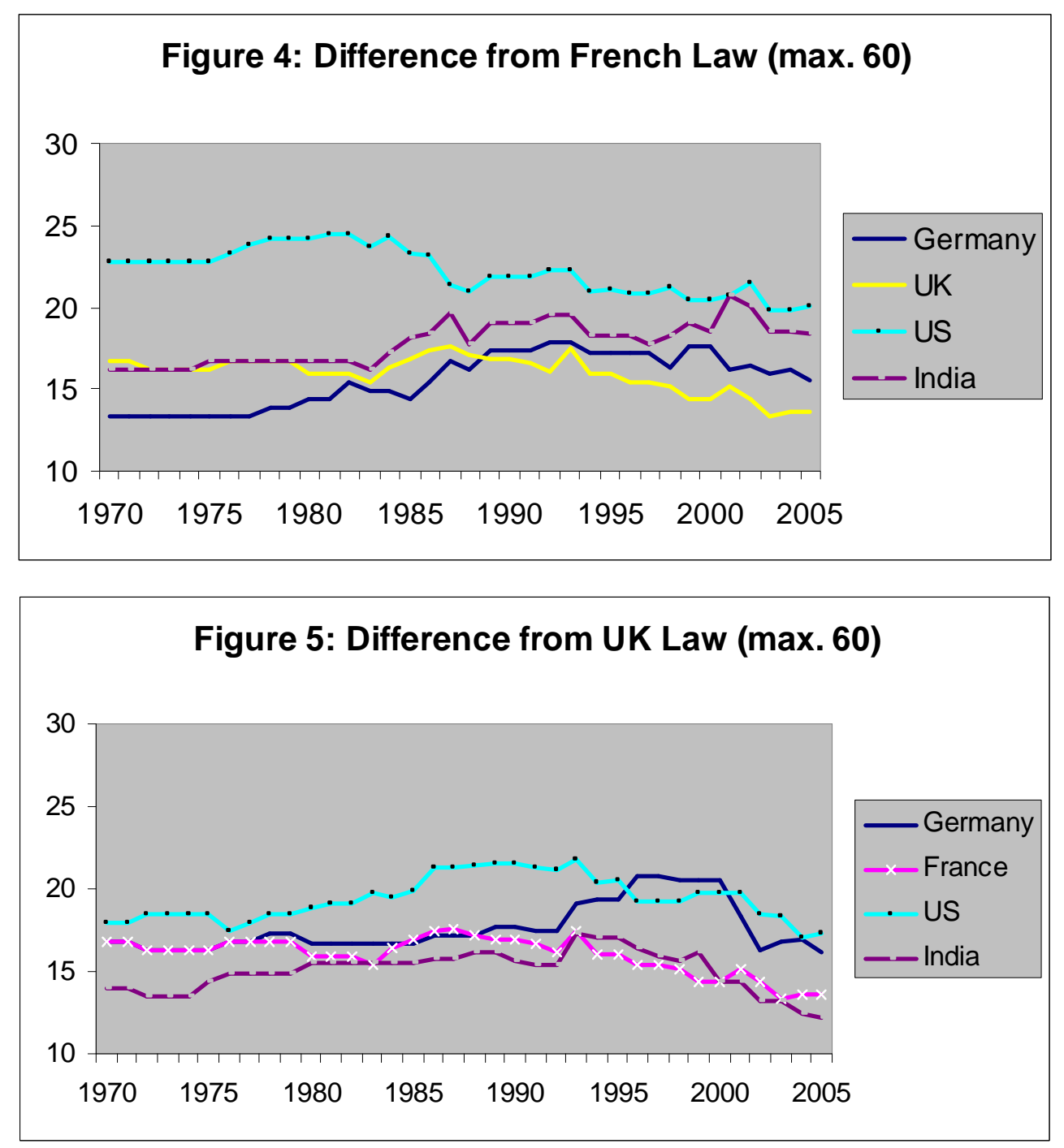
With respect to the difference the from French law in Figure 4 the most interesting curves are the ones that represent Germany and the UK. One may expect that German and French law would be least different because both countries belong to the civil-law family and in both countries blockholders have typically dominated public companies. This can indeed be confirmed until the late 80s. Since then, however, UK law is the least different from French law, because French and UK law have converged ${ }^{111}$ and French and German law have diverged. ${ }^{112}$ Path dependencies based on legal families have not prevented this development. Furthermore, it is interesting to note that all along the indices for the two European countries (UK and Germany) have had values considerably more similar to French law values than the two non-European countries (US and India). Here again communication between the European countries or even a common European legal culture appear to be stronger than the categorisation into different legal families.

With respect to the difference from UK law in Figure 5, Indian law is least different, then French law, then German law and once again US law is the most different. Indian law is predictably similar to UK law, because of its common-law legal origin. But it has developed certain features of its own to suit its socio-economic conditions, for example, the law in relation to public enforcement of company law ${ }^{113}$ and these variables seem to ensure a constant difference between the two countries for the entire duration of the time-series. Furthermore changes in UK law ${ }^{114}$ have taken the two countries further away from each other during the 90s. But the introduction of corporate governance provisions based largely on the UK codes has reduced the difference in the last few years. ${ }^{115}$ A comparable recent development can also be seen for the other countries. It is remarkable, however, that for almost the entire period French law

\footnotetext{
${ }^{111}$ Eg comparing our data on the shareholder protection in 1980 and 2005, there are now less differences between the two countries with respect to proxy voting (variable I 4), shares not blocked (variable I 6), board division (variable I 9.1), duty of care (variable I 13), and disclosure of major shareholder ownership (variable II 8).

${ }^{112}$ Eg comparing our data on the shareholder protection in 1980 and 2005, there are now more differences between the two countries with respect to the power of the general meeting for de-facto changes (variable I 1.4), proxy voting (variable I 4), individual information rights (variable I 5), the right to access the register of shareholders (variable I 8.1), the "one share one vote" principle (variable II 3), and appraisal rights (variable II 7).

${ }^{113}$ See infra Annex I, variable I 18.

${ }^{114}$ See supra nn 75-76.

${ }^{115}$ Clause 49 of the Listing Agreement, introduced in 2000 by the SEBI, vide its circular dated 21-22000 and implemented from 2001 onwards.
} 
has been quite similar to UK law and that US law has been very different to it. ${ }^{116}$ Our results therefore contradict any claims to the effect that there are deep differences between shareholder protection in the Civil Law and the Common Law origin countries. $^{117}$

For lack of space the similar outcomes about differences from German, Indian, and the US law have not been included in this article. However, the next two figures display differences between all the countries and therefore compensate for their absence. Figure 6 shows the mean of all the differences of all five countries from every other country. For example, the US curve indicates how different US law is from the law of the UK, Germany, France, and India. Once again, a score of " 0 " would mean that it were completely identical and " 60 " would mean that it were completely different. Finally, Figure 7 displays the mean of the five curves of Figure 6.

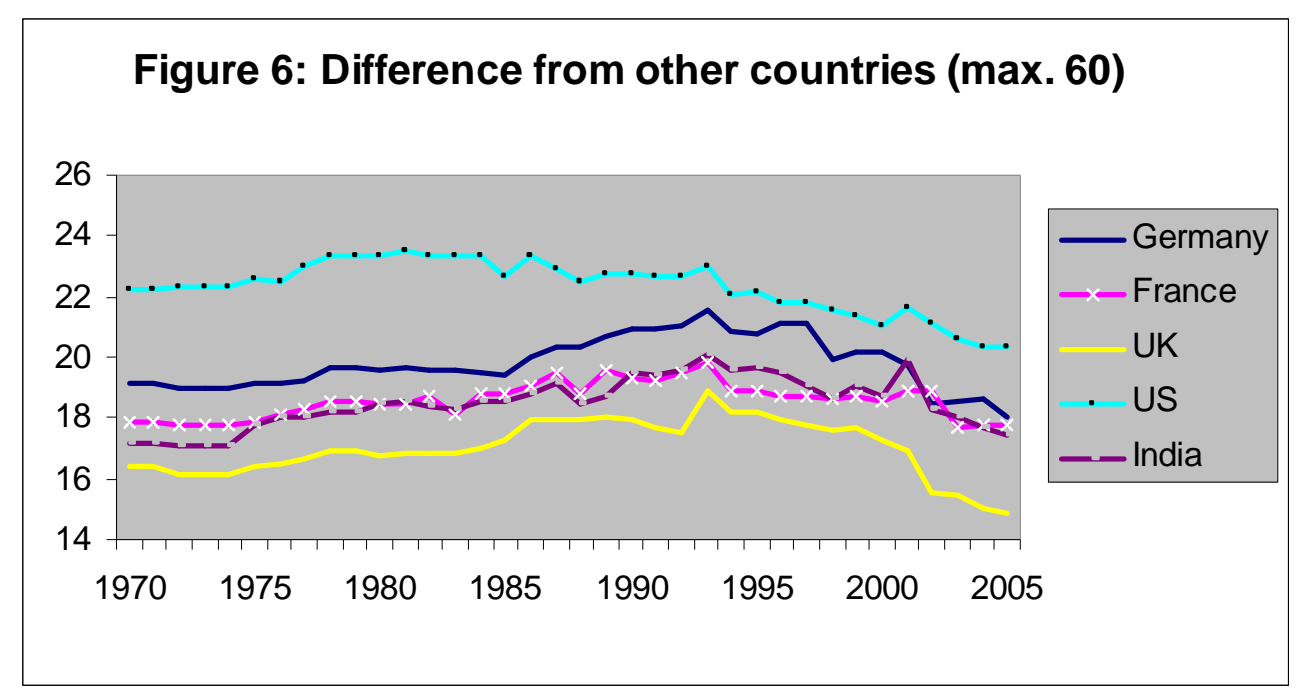

\footnotetext{
${ }^{116}$ Differences between US and UK law concern, eg the power of the general meeting (variable I 1), the right to call an extraordinary shareholder meeting (variable I 3), proxy voting (variable I 4), duration of director's appointment (variable I 13), board neutrality in case of takeovers (variable I 14.2), supermajority requirements (variable II 2), the mandatory bid (variable II 7.2), pre-emptive rights (variable II 15), and entrenched boards (variable II 10.2).

${ }^{117}$ For such claims see La Porta et al, supra n 7; Djankov et al, supra n 9.
} 


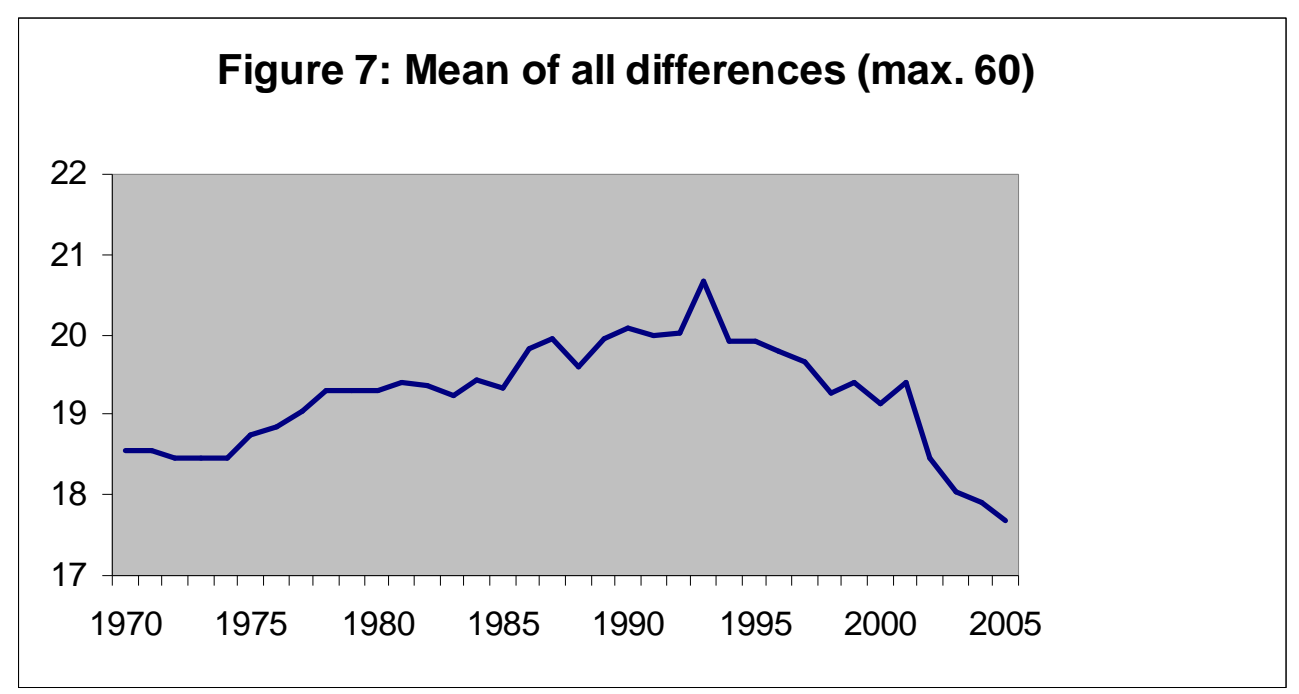

The fact that in Figure 6 the US curve has the highest scores means that US law has always been more different than the law of the other four countries. The fact that the US curve has been climbing down a few points every now and then and especially since 2000 may indicate some Americanisation of the law of the other countries. Indeed, our data suggests that, in some respect, the law of the other countries has become more similar to US law. ${ }^{118}$ Equally, with respect to some variables US law has become more similar to the law of the other countries. ${ }^{119}$ But, given the continuing differences between US law and the law of the other countries, Figure 6 suggests that there is no general Americanisation of the law on shareholder protection. It is also interesting that UK law has always been more "mainstream" i.e. the UK law has been the least different from all the other countries than the law of the other countries. The explanation for this could be that the UK is both a member of the common-law and the European family, and thus influences and/or absorbs different legal traditions. Finally, it is remarkable that the curves of the five countries hardly ever overlap with each other. The differences in the level of internationality are therefore fairly stable. Perhaps this degree to which a country takes foreign ideas into account is a deep factor of legal culture which does not change considerably over time.

\footnotetext{
${ }^{118}$ This concerns, in particular, the variables on proxy voting (variable I 4), committees (variable I 9.2), performance based remuneration (variable I 11), private enforcement (variable I 13.3), one share one vote (variable II 3), and disclosure of major shareholder ownership (variable II 8).

${ }^{119}$ In particular, the variables on board division (variable I 9.1), general meeting power for remuneration (variable I 10.1), public enforcement (variable I 18.3), and shareholder protection mandatory (variable II 10).
} 
The dropping curves in Figure 6 indicate that the law of the five countries is converging in the last years. This overall tendency becomes even clearer in Figure 7. Two points in time are particularly important: 1993/1994 and 2001/2002. During 1993/1994, France made its law more flexible, ${ }^{120}$ whereas in the UK the Cadbury Code of Best Practice was applied ${ }^{121}$. This led to a divergence, but in the succeeding years the other countries followed the UK model and enacted similar corporate governance codes. The convergence has increased significantly since the year 2001/2002. Following the burst of the dot-com bubble and the string of corporate scandals at the beginning of the century in many parts of the world, all five countries changed the law in a similar pattern. Consequently, Figure 7 indicates that globalisation in shareholder protection indeed may be taking place. ${ }^{122}$

\section{E. ConClusion}

In this article we have built a new and meaningful shareholder protection index for five countries and coded the development of the law for over three decades. Attributing and comparing legal differences by numbers is contrary to the traditional way of doing comparative law and the use of a quantitative methodology to account for variations across legal systems has been subjected to some searching criticisms. ${ }^{123}$ However, we believe that with a cautious approach, it has the potential to open new vistas of research in the area of comparative law and as such should not be shunned. In fact, this article provides an illustration of the interesting possibilities that diligent quantification of legal rules provides for comparing variations across time series and across legal systems.

\footnotetext{
${ }^{120}$ And thus the values of variables I 12.2, II 1, 6 dropped.

${ }^{121}$ And thus the values of variables I 9.1-3, 12.2, 17 rose.

${ }^{122}$ Non-quantitative research disagrees about this fact; see, eg JN Gordon and MJ Roe (eds), Convergence and Persistence in Corporate Governance (Cambridge University Press, 2004); BH McDonnell, "Convergence in Corporate Governance - Possible, but not Desirable" (2002) 47 Villanova Law Review 341; DM Branson, "The Very Uncertain Prospect of 'Global' Convergence in Corporate Governance" (2001) 34 Cornell International Law Journal 321; RJ Gilson, "Globalizing Corporate Governance: Convergence of Form or Function" (2001) 49 American Journal of Comparative Law 329; H Hansmann and R Kraakman, "The End of History for Corporate Law" (2001) 88 Georgetown Law Journal 439; Siems, supra n 45.

${ }^{123}$ See supra $\mathrm{n} 48$.
} 
Our leximetric study has found, first, that in all of the countries studied (UK, US, Germany, France, India), shareholder protection has been improving in the last 35 years. Secondly, our data shows that the law on shareholder protection in the US is weaker than the law of the other four countries. ${ }^{124}$ Thirdly, we have found that one of the reasons for this is that the protection of minority against majority shareholders is considerably stronger in the "blockholder countries" - France, Germany, and India. Fourthly, our examination of the legal differences between the five countries does not confirm the distinction between common law and civil law countries. Our results therefore suggest that on diligent coding of shareholder protection law based on a meaningful shareholder protection index in particular taking into account functional equivalents of legal instruments for protection - the claims that there are deep differences between shareholder protection in the Civil Law and the Common Law countries seem to wither away. Finally, we found that convergence in shareholder protection has been taking place since 1993 and has increased considerably since 2001.

It should be noted that we have not examined whether a better "score" in our shareholder protection index does matter for good corporate governance and ultimately for economic development of a country. It could be the case that more shareholder protection hinders companies ${ }^{125}$ and thus has a contrary effect. We will, however, be examining this question in the future when our indices will constitute a basis for an econometric study combining financial data to find statistical relationships between legal and economic data. ${ }^{126}$

\footnotetext{
${ }^{124}$ However, this observation concerns only the aggregates; for the problem of weighting variables see supra, Section C 2 (e).

${ }^{125}$ See supra, Section D 1 (c).

${ }^{126}$ See supra 6.
} 
ANNEX I: SHAREHOLDER PROTECTION INDEX (VARIABLES)

\begin{tabular}{|c|c|}
\hline Variables & Description $^{127}$ \\
\hline $\begin{array}{l}\text { I. Protection } \\
\text { against board } \\
\text { and management }\end{array}$ & \\
\hline $\begin{array}{l}\text { 1. Powers of the } \\
\text { general meeting }\end{array}$ & $\begin{array}{l}\text { The following variables equal } 0 \text { if there is no power of the general meeting and } 1 \\
\text { if there is a power of the general meeting.. } \\
\text { (1) Amendments of articles of association } \\
\text { (2) Mergers and divisions } \\
\text { (3) Capital measures } 29 \\
\text { (4) De facto changes: The decisive thresholds are the sale of subtantial as- } \\
\text { sets of the company (e.g., if the sale of more than } 50 \% \text { requires ap- } \\
\text { proval of the general meeting it equals } 1 \text {; if more than } 80 \% \text {, it equals } \\
0.5 \text {; and otherwise } 0 \text { ). } \\
\text { (5) Dividend distributions: Equals } 1 \text { if the general meeting can effectively } \\
\text { influence the amount of dividend (e.g., if it decides about the annual } \\
\text { accounts and the annual dividend, and if the board has no significant } \\
\text { possibility of "manipulating" the accounts); equals } 0.5 \text { if there is some } \\
\text { participation of the general meeting; equals } 0 \text { if it is only the board that } \\
\text { decides about the dividend. } \\
\text { (6) Election of board of directors } \\
\text { (7) Directors" self-dealing of substantial transactions }\end{array}$ \\
\hline $\begin{array}{l}\text { 2. Agenda setting } \\
\text { power }^{130}\end{array}$ & $\begin{array}{l}\text { (1) General topics: Equals } 1 \text { if shareholders who hold } 1 \% \text { or less of the } \\
\text { capital can put an item on the agenda; equals } 0.5 \text { if there is a hurdle of } \\
\text { more than } 1 \% \text { but less than } 10 \% \text {; equals } 0 \text { otherwise. } \\
\text { (2) Election of directors: ditto } \\
\text { (3) Costs: Equals } 1 \text { if shareholders do not have to pay for their proposals; } \\
\text { equals } 0 \text { otherwise. }\end{array}$ \\
\hline $\begin{array}{l}\text { 3. Extraordinary } \\
\text { shareholder meet- } \\
\text { ing }\end{array}$ & $\begin{array}{l}\text { (1) Right: Equals } 1 \text { if the minimum percentage of share capital to demand } \\
\text { an extraordinary meeting is less than or equal to } 5 \% \text {; equals } 0.5 \text { if it is } \\
\text { more than } 5 \% \text { but less or equal than } 10 \% \text {; equals } 0 \text { otherwise. } \\
\text { (2) Enforcement: Equals } 1 \text { if shareholders can call the meeting themselves } \\
\text { or have a right that the court will enforce it; equals } 0 \text { if the court has } \\
\text { discretion. }\end{array}$ \\
\hline $\begin{array}{l}\text { 4. Anticipation of } \\
\text { shareholder deci- } \\
\text { sion }\end{array}$ & $\begin{array}{l}\text { (1) Restrictions on proxy voting: Equals } 0 \text { if there are restrictions on who } \\
\text { can be appointed or which rights the proxy has so that it is likely that } \\
\text { proxy voting does usually not take place; equals } 0.5 \text { if there are some } \\
\text { restrictions which reduce the relevance of proxy voting; equals } 1 \text { if }\end{array}$ \\
\hline
\end{tabular}

${ }^{127}$ Even where the description of the variables does not mention so specifically, we have given intermediate scores wherever necessary. See supra, C 2 (f) on non-binary coding.

${ }^{128}$ For the power of the general meeting for remuneration see variable I 10.1.

${ }^{129}$ The possibility of authorised capital does not lead to a reduction from 1 to 0.5 because the default rule does not change.

${ }^{130}$ Variables I. 2 and 3 could also be used as mechanisms for protecting minority from majority shareholders. However, in this study we have considered them as part of protection against directors because the directors are responsible for and decide the agenda and the calling of the shareholders meetings and therefore the legal rules of these variables primarily protect shareholders against directors.

${ }^{131}$ See supra $\mathrm{n} 130$. 


\begin{tabular}{|c|c|}
\hline & $\begin{array}{l}\text { there are no restrictions. } \\
\text { (2) Anticipation facilitated: Equals } 1 \text { if postal voting or proxy solicitation } \\
\text { with two-way voting proxy form has to be provided by the company; } \\
\text { equals } 0.5 \text { if two-way proxy form has to be provided but not proxy so- } \\
\text { licitation; equals } 0 \text { otherwise. } \\
\text { (3) Costs of proxy contest: Equals } 1 \text { if the costs of proxy solicitations are } \\
\text { paid by the company or if proxies have the right to have their proposals } \\
\text { included in the company's proxy form; equals } 0 \text { otherwise. }\end{array}$ \\
\hline $\begin{array}{l}\text { 5. Information in } \\
\text { the run-up of the } \\
\text { general meeting }\end{array}$ & $\begin{array}{l}\text { (1) Amendments of the articles of association: Equals } 1 \text { if the exact word- } \\
\text { ing has to be sent in advance ("push-system"); equals } 0.5 \text { if the share- } \\
\text { holders have to request it ("pull-system"); equals } 0 \text { otherwise. } \\
\text { (2) Mergers: Equals } 1 \text { if a special report has to be sent in advance ("push- } \\
\text { system"); equals } 0.5 \text { if the shareholders have to request it ("pull- } \\
\text { system"); equals } 0 \text { otherwise. }\end{array}$ \\
\hline $\begin{array}{l}\text { 6. Shares not } \\
\text { blocked before } \\
\text { general meeting }\end{array}$ & $\begin{array}{l}\text { Equals } 0 \text { if shareholders have to deposit their shares prior to the general meeting } \\
\text { and if this has the consequence that shareholders are prevented from selling their } \\
\text { shares for a number of days; equals } 1 \text { otherwise. }\end{array}$ \\
\hline $\begin{array}{l}\text { 7. Individual in- } \\
\text { formation rights }\end{array}$ & $\begin{array}{l}\text { (1) Right to demand information (1): equals } 1 \text { if an individual shareholder } \\
\text { or shareholders with } 5 \% \text { or less capital can demand information which } \\
\text { will be answered at the general meeting; equals } 0.5 \text { if shareholders with } \\
10 \% \text { or less capital have this right; equals } 0 \text { otherwise. } \\
\text { (2) Right to demand information (2): equals } 1 \text { if an individual shareholder } \\
\text { or shareholders with } 5 \% \text { or less capital can demand information inde- } \\
\text { pendent of the general meeting; equals } 0.5 \text { if shareholders with } 10 \% \text { or } \\
\text { less capital have this right; equals } 0 \text { otherwise. }\end{array}$ \\
\hline $\begin{array}{l}\text { 8. Communication } \\
\text { with other share- } \\
\text { holders }\end{array}$ & $\begin{array}{l}\text { (1) Right to access the register of shareholders and (if necessary) beneficial } \\
\text { owners: Equals } 1 \text { if the right of inspection can be used by a single } \\
\text { shareholder; equals } 0 \text { if there is no such right. } \\
\text { (2) Equals } 1 \text { if communication is not affected by proxy rules; equals } 0 \text { oth- } \\
\text { erwise. }\end{array}$ \\
\hline $\begin{array}{l}\text { 9. Board composi- } \\
\text { tion }\end{array}$ & $\begin{array}{l}\text { (1) Division between management and control: Equals } 1 \text { if there is a two- } \\
\text { tier system or at least half of the board members are non-executive; } \\
\text { equals } 0.5 \text { if at least } 25 \% \text { of the board members are non-executive; } \\
\text { equals } 0 \text { otherwise. } \\
\text { (2) Independent board members: }{ }^{132} \text { Equals } 1 \text { if at least half of the board } \\
\text { members must be independent; equals } 0.5 \text { if at least } 25 \% \text { of them must } \\
\text { be independent or if the independence requirement is very low; equals } 0 \\
\text { otherwise. } \\
\text { (3) Committees: Equals } 1 \text { if companies have to install an audit and a remu- } \\
\text { neration committee with a majority of independent members; interme- } \\
\text { diate scores are possible if the requirement is partial, (for instance re- } \\
\text { quires setting up of one of the committees or the independent members } \\
\text { of the committees constitute less than a majority); equals } 0 \text { if commit- } \\
\text { tees are not necessary or if they are not required to have independent } \\
\text { members. }\end{array}$ \\
\hline $\begin{array}{l}\text { 10.No excessive } \\
\text { remuneration for } \\
\text { non-executive and }\end{array}$ & $\begin{array}{l}\text { (1) General meeting power: }{ }^{133} \text { Equals } 1 \text { if the general meeting has to ap- } \\
\text { prove all compensation schemes; equals } 0.5 \text { if this is limited (e.g., ap- } \\
\text { plies to stock option plans only, or if some directors are excluded); }\end{array}$ \\
\hline
\end{tabular}

${ }^{132}$ To be sure, independent board members may also be a method to protect minority shareholders against majority shareholders. This depends, however, on the definition of "independence", which is not coded in this variable.

${ }^{133}$ For the involvement of boards and committees see generally variable I 9. 


\begin{tabular}{|c|c|}
\hline $\begin{array}{l}\text { executive } \\
\text { directors }\end{array}$ & $\begin{array}{l}\text { equals } 0 \text { otherwise. } \\
\text { (2) Annual disclosure: Equals } 1 \text { if there is full and specific disclosure about } \\
\text { the individual remuneration of each director; equals } 0.75 \text { if there is in- } \\
\text { formation about the individual remuneration of some directors; equals } \\
0.5 \text { if there is disclosure about the top } 2 \text { directors (executives); equals } \\
0.25 \text { if there is only disclosure about the overall remuneration; equals } 0 \\
\text { otherwise. } \\
\text { (3) Substantive requirements placing limit for remuneration in order to pro- } \\
\text { tect shareholders: Equals } 1 \text { if there is a direct regulation; equals } 0 \text { oth- } \\
\text { erwise }\end{array}$ \\
\hline $\begin{array}{l}11 . \text { Performance } \\
\text { based remuneration }\end{array}$ & $\begin{array}{l}\text { Equals } 1 \text { if performance based remuneration of directors and managers is fos- } \\
\text { tered (e.g. facilitation of stock options to reward performance); equals } 0 \text { other- } \\
\text { wise. }\end{array}$ \\
\hline $\begin{array}{l}\text { 12. Duration of } \\
\text { director's appoint- } \\
\text { ment }\end{array}$ & $\begin{array}{l}\text { (1) Normal duration: Equals } 1 \text { if this is one year or less; } 0 \text { if this is five } \\
\text { years or more; equals } 0.5 \text { if this is more than } 1 \text { but less than } 5 \text { years . } \\
\text { (2) Dismissal feasible: Equals } 1 \text { if there are no special requirements; equals } \\
0 \text { if an important or good reason is required; intermediate scores are } \\
\text { possible if there are no special requirements but there may be financial } \\
\text { burden for the company (e.g. in the form of compensation under a stat- } \\
\text { ute or contract or damages for breach of contract or salary under a fixed } \\
\text { term contract). }\end{array}$ \\
\hline $\begin{array}{l}\text { 13. Directors du- } \\
\text { ties }^{134}\end{array}$ & $\begin{array}{l}\text { (1) Directors" liability - duty of care: Equals } 0 \text { if there are narrow criteria } \\
\text { which virtually exclude liability; equals } 0.5 \text { if there are some restric- } \\
\text { tions (e.g., business judgement rule; gross negligence); equals } 1 \text { if there } \\
\text { are no or little restrictions regarding business judgement and standard } \\
\text { of care. } \\
\text { (2) Directors" liability - duty of loyalty: Equals } 1 \text { if there is a duty not to } \\
\text { put personal interests ahead of the company; equals } 0 \text { otherwise. } \\
\text { (3) Private enforcement: Equals } 0 \text { if this is typically excluded (e.g., because } \\
\text { of strict subsidiarity requirement, hurdle which is at least } 10 \% \text {; cost } \\
\text { rules); equals } 0.5 \text { if there are some restrictions [e.g., certain percentage } \\
\text { of share capital (unless the hurdle is at least } 10 \% \text { ); cost rules; demand } \\
\text { requirement]; equals } 1 \text { otherwise. }\end{array}$ \\
\hline $\begin{array}{l}\text { 14. Shareholder } \\
\text { supremacy }\end{array}$ & $\begin{array}{l}\text { (1) General principle: Equals } 1 \text { if the board always has to give priority to } \\
\text { shareholders interests; equals } 0 \text { if the board have to give priority to the } \\
\text { interests of other stakeholders; equals } 0.5 \text { in other cases. } \\
\text { (2) Takeover law: Equals } 1 \text { if there is the principle of strict neutrality in } \\
\text { case of takeovers; equals } 0.5 \text { if the principle of neutrality is subject to } \\
\text { exceptions; equals } 0 \text { otherwise. }\end{array}$ \\
\hline $\begin{array}{l}\text { 15. Pre-emptive } \\
\text { right }^{136}\end{array}$ & $\begin{array}{l}\text { Equals } 1 \text { when the law grants shareholders the first opportunity to buy new is- } \\
\text { sues of shares, and this right can be waived only by the general meeting; }{ }^{137} \\
\text { equals } 0 \text { otherwise. }\end{array}$ \\
\hline
\end{tabular}

${ }^{134}$ For approval of directors' conduct by the general meeting, the supervisory board, or independent board members see variables I 1, 9; for exclusion of liability in the articles see variable II 10.1 .

${ }^{135}$ For preventive measures see, eg variable II 3.

${ }^{136}$ Usually, the directors decide about the issuance of new shares. Pre-emptive right is perceived as an important protection against directors as it prevents them from disregarding the interests of shareholders in general. Of course, in some cases this may also be a method to protect minority against majority shareholders.

${ }^{137}$ For the requirements for a waiver (eg supermajority, good reason) see variables II 2, 9. 


\begin{tabular}{|l|l|}
\hline $\begin{array}{l}\text { 16. Director's dis- } \\
\text { qualification }\end{array}$ & $\begin{array}{l}\text { Equals 1 if negligent conduct can lead to disqualification; 0.5 if directors are } \\
\text { disqualified only in specific instances of negligence (e.g., failure of financial } \\
\text { reporting); equals 0 if negligent conduct itself is not sufficient for disqualifica- } \\
\text { tion }\end{array}$ \\
\hline $\begin{array}{l}\text { 17. Corporate gov- } \\
\text { ernance code }\end{array}$ & $\begin{array}{l}\text { Equals 1 if companies have to disclose and explain whether they comply with a } \\
\text { corporate governance code; equals 0.5 if this is only recommended; equals 0 } \\
\text { otherwise. }\end{array}$ \\
\hline $\begin{array}{l}\text { 18. Public en- } \\
\text { forcement of com- } \\
\text { pany law }\end{array}$ & $\begin{array}{l}\text { The following variables equal 0 if there is no power of public authority and 1 if } \\
\text { public authority has power. } \\
\text { (1) Authorisation for director's self dealing of substantial transactions } \\
\text { (2) Authorisation for appointment of managers } \\
\text { (3) Power to intervene in cases of prejudice to public interest or interest of } \\
\text { the company for instance due to "mismanagement of company" or in } \\
\text { cases of oppression of shareholders }\end{array}$ \\
\hline
\end{tabular}

\begin{tabular}{|c|c|}
\hline $\begin{array}{l}\text { II. Protection } \\
\text { against other } \\
\text { shareholder }\end{array}$ & \\
\hline 1. Quorum ${ }^{138}$ & $\begin{array}{l}\text { Equals } 1 \text { if there is a } 50 \% \text { quorum for the extraordinary shareholder meeting } \\
\text { (when it is called for the first time); equals } 0.5 \text { if the quorum is } 1 / 3 \text {; equals } 1 / 4 \text { if } \\
\text { the quorum is } 1 / 4 \text {. Equals } 0 \text { otherwise. }\end{array}$ \\
\hline $\begin{array}{l}\text { 2. Supermajority } \\
\text { requirements }\end{array}$ & $\begin{array}{l}\text { Equals } 1 \text { if there are supermajority requirements (e.g., } 2 / 3 \text { or } 3 / 4 \text { ) for amend- } \\
\text { ments of the articles of association, mergers, and voluntary liquidations; equals } 0 \\
\text { if they do not exist at all. }\end{array}$ \\
\hline $\begin{array}{l}\text { 3. One share - one } \\
\text { vote }^{139}\end{array}$ & $\begin{array}{l}\text { (1) Default rule: Equals } 1 \text { if this principle exists as a default rule; equals } 0 \\
\text { otherwise. } \\
\text { (2) Prohibition of multiple voting rights (super voting rights): Equals } 1 \text { if } \\
\text { there is a prohibition; equals } 2 / 3 \text { if only companies which already have } \\
\text { multiple voting rights can keep them; equals } 1 / 3 \text { if state approval is } \\
\text { necessary; equals } 0 \text { otherwise. } \\
\text { (3) Prohibition of capped voting rights (voting right ceilings): Equals } 1 \text { if } \\
\text { there is a prohibition; equals } 2 / 3 \text { if only companies which already have } \\
\text { voting caps can keep them; equals } 1 / 3 \text { if state approval is necessary; } \\
\text { equals } 0 \text { otherwise. }\end{array}$ \\
\hline $\begin{array}{l}\text { 4. Cumulative vot- } \\
\text { ing }\end{array}$ & $\begin{array}{l}\text { Equals } 1 \text { if shareholders can cast all their votes for one candidate standing for } \\
\text { election to the board of directors or if there exists a mechanism of proportional } \\
\text { representation in the board by which minority interests may name a proportional } \\
\text { number of directors to the board (default or mandatory law); equals } 0 \text { otherwise. }\end{array}$ \\
\hline $\begin{array}{l}\text { 5. Voting by inter- } \\
\text { ested shareholders } \\
\text { prohibited }\end{array}$ & $\begin{array}{l}\text { Equals } 1 \text { if a shareholder cannot vote if this vote favours him or her personally } \\
\text { (i.e., only "disinterested shareholders" can vote); equals } 0 \text { otherwise. }\end{array}$ \\
\hline
\end{tabular}

${ }^{138}$ The purpose of requiring a substantial percentage of shareholders to constitute a valid quorum could be to prevent decisions of the general meeting which are not supported by a significant majority much like the supermajority requirements. But see also supra, Section D 1 (c) and n 99.

${ }^{139}$ Preference shares without voting rights are not addressed because they are feasible in all countries. 


\begin{tabular}{|c|c|}
\hline $\begin{array}{l}\text { 6. No squeeze out } \\
\text { (freeze out) }\end{array}$ & $\begin{array}{l}\text { Equals } 0 \text { if a shareholder holding } 90 \% \text { or more can "squeeze out" the minority; } \\
\text { equals } 1 \text { otherwise. }\end{array}$ \\
\hline 7. Right to exit & $\begin{array}{l}\text { (1) Appraisal rights: Equals } 1 \text { if they exist for mergers, amendments of the } \\
\text { articles and sales of major company assets; equals } 0 \text { if they do not exist } \\
\text { at all. } \\
\text { (2) Mandatory bid: Equals } 1 \text { if there is a mandatory bid for the entirety of } \\
\text { shares in case of purchase of } 30 \% \text { or } 1 / 3 \text { of the shares; equals } 0 \text { if there } \\
\text { is no mandatory bid at all. } \\
\text { (3) Mandatory public offer: Equals } 1 \text { if there is a mandatory public offer } \\
\text { for purchase of } 10 \% \text { or less of the shares; equals } 0.5 \text { if the acquirer has } \\
\text { to make a mandatory public offer for acquiring more than } 10 \% \text { but less } \\
\text { than } 30 \% \text { of the shares; equals } 0 \text { otherwise. }\end{array}$ \\
\hline $\begin{array}{l}\text { 8. Disclosure of } \\
\text { major share owner- } \\
\text { ship }\end{array}$ & $\begin{array}{l}\text { Equals } 1 \text { if shareholders who acquire at least } 3 \% \text { of the companies capital have } \\
\text { to disclose it; equals } 0.75 \text { if this concerns } 5 \% \text { of the capital; equals } 0.5 \text { if this } \\
\text { concerns } 10 \% \text {; equals } 0.25 \text { if this concerns } 25 \% \text {; equals } 0 \text { otherwise }\end{array}$ \\
\hline $\begin{array}{l}\text { 9. Oppressed mi- } \\
\text { nority }\end{array}$ & $\begin{array}{l}\text { (1) Substantive law: Equals } 0 \text { if majority decisions of the general meeting } \\
\text { have to be accepted by the outvoted minority; equals } 1 \text { if some kind of } \\
\text { substantive control is possible (e.g., in cases of amendments to the arti- } \\
\text { cles of association, ratification of management misconduct, exclusion } \\
\text { of the pre-emption right, related parties transactions, freeze outs); } \\
\text { equals } 0.5 \text { if this control covers only flagrant abuses of majority power. } \\
\text { (2) Shareholder action: Equals } 1 \text { if every shareholder can file a claim } \\
\text { against a resolution by the general meeting because he or she regards it } \\
\text { as void or voidable; equals } 0.5 \text { if there are hurdles such as a threshold } \\
\text { of at least } 10 \% \text { voting rights or cost rules; equals } 0 \text { if this kind of } \\
\text { shareholder action does not exist. }\end{array}$ \\
\hline $\begin{array}{l}\text { 10. Shareholder } \\
\text { protection is man- } \\
\text { datory }{ }^{140}\end{array}$ & $\begin{array}{l}\text { (1) Exclusion of directors duty of care (see variable I 13.1) in articles: } \\
\text { equals } 0 \text { if possible and equals } 1 \text { otherwise. } \\
\text { (2) Rules on duration of director's appointment (see variable I } 12.1 \text { and 2): } \\
\text { equals } 1 \text { if mandatory and } 0 \text { otherwise. } \\
\text { (3) Board composition (supervisory boards, non-executive directors) (see } \\
\text { variable I } 9.1 \text { and } 2 \text { ): equals } 1 \text { if mandatory and } 0 \text { otherwise. } \\
\text { (4) Other topics: equals } 1 \text { if there is the general rule that company law is } \\
\text { mandatory; equals } 0 \text { if company law is in general just a "model off the } \\
\text { shelf"; equals } 0.5 \text { if there is no general rule. }\end{array}$ \\
\hline
\end{tabular}

${ }^{140}$ Note: Variables II 10.1-3 do not code the content of the law (this is already done in variables I 9.1-2, $12,13.1)$ but only its nature, i.e. whether "mandatory" or "default". 


\title{
ANNEX II: SHAREHOLDER PROTECTION INDEX (EXTRACT - FRANCE)
}

\section{Shareholder Protection France ${ }^{1}$}

\begin{tabular}{|c|c|c|c|c|c|c|c|c|c|c|c|c|}
\hline & 70 & 71 & 72 & 73 & 74 & 75 & 76 & 77 & 78 & 79 & 80 & 81 \\
\hline \multirow[t]{7}{*}{ I 1} & $1^{2}$ & 1 & 1 & 1 & 1 & 1 & 1 & 1 & 1 & 1 & 1 & 1 \\
\hline & $1^{3}$ & 1 & 1 & 1 & 1 & 1 & 1 & 1 & 1 & 1 & 1 & 1 \\
\hline & $1^{4}$ & 1 & 1 & 1 & 1 & 1 & 1 & 1 & 1 & 1 & 1 & 1 \\
\hline & $0^{5}$ & 0 & 0 & 0 & 0 & 0 & 0 & 0 & 0 & 0 & 0 & 0 \\
\hline & $1 / 26$ & $1 / 2$ & $1 / 2$ & $1 / 2$ & $1 / 2$ & $1 / 2$ & $1 / 2$ & $1 / 2$ & $1 / 2$ & $1 / 2$ & $1 / 2$ & $1 / 2$ \\
\hline & $1^{7}$ & 1 & 1 & 1 & 1 & 1 & 1 & 1 & 1 & 1 & 1 & 1 \\
\hline & $1^{8}$ & 1 & 1 & 1 & 1 & 1 & 1 & 1 & 1 & 1 & 1 & 1 \\
\hline
\end{tabular}

\begin{abstract}
${ }^{1}$ Main laws on shareholder protection: Loi no 66-537 du 24 juillet 1966 sur les sociétés commerciales (in 2000 repealed); since Ordonnance No. 2000-912 company law is (again) regulated in the Code de Commerce (subsequently amended, e.g., by Loi sur les nouvelles régulations économiques (NRE) no 2001-420 du 15 mai 2001); Décret no 67-236 sur les sociétés commerciales (as amended); Règlement général de l'Autorité des marchés financiers 2004; Code monétaire et financier 2000; Principes de gouvernement d'entreprise résultant de la consolidation des rapports conjoints de l'AFEP (Association Française des Entreprises Privées) et du MEDEF (Mouvement des Entreprises de France) 2003 (French Corporate Governance Principles).
\end{abstract}

${ }^{2}$ Loi 1966, art. 153; Code de Commerce 2000, art. L. 225-96.

${ }^{3}$ Loi 1966, art. 376; Code de Commerce 2000, art. L. 236-9.

${ }^{4}$ Loi 1966, arts. 180, 215; Code de Commerce 2000, arts. L. 225-129, 225-204.

${ }^{5}$ There is no explicit provision on sale of major parts of company assets. It is debated, first, whether a de facto measure constitutes a change in the object of business (as indicated in the articles), for which the general meeting is competent. Second, it is argued that the major assets can be equated with the whole assets (Loi 1966, art. 396 (no.4); Code de Commerce 2000, art. L. 237-8(no.4)) (see generally, Siems, supra note 45, at 217). Since these cases are exceptions, and since there is no case law, deviation from the " 0 " score would, however, not be justified.

${ }^{6}$ The general meeting decides both approval of the annual accounts and the distribution of profits (Loi 1966, arts. 346, 347; Code de Commerce 2000, arts. L. 232-11, 232-12). However, there is some room for manoeuvre due to accounting law. Furthermore, interim dividends are possible (Loi 1966, art. 347; Code de Commerce 2000, arts. L. 232-12, Décret 1967, art. 200).

${ }^{7}$ Loi 1966, arts. 90, 134; Code de Commerce 2000, arts. L. 225-18, 225-75.

${ }^{8}$ Loi 1966, arts. 101 though 103; Code de Commerce 2000, arts. L. 225-38 though 40 (but not if normal terms and conditions). 